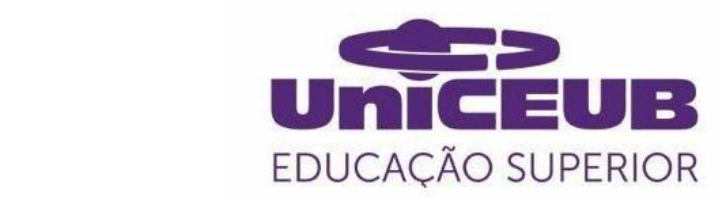

CENTRO UNIVERSITÁRIO DE BRASÍLIA- UnICEUB

PROGRAMA DE INICIAÇÃO CIENTÍFICA

MURILO HENRIQUE RODRIGUES

LÍVIA FERREIRA BOARO

REAPROVEITAMENTO DE RESÍDUO DE GRANALHA DE AÇO NA COMPOSIÇÃO

DE CONCRETO

BRASÍLIA

2020 


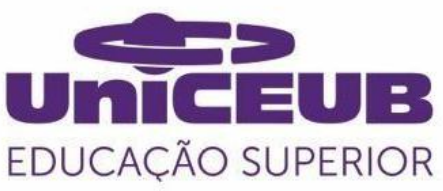

MURILO HENRIQUE RODRIGUES

LÍVIA FERREIRA BOARO

\section{REAPROVEITAMENTO DE RESÍDUO DE GRANALHA DE AÇO NA COMPOSIÇÃO DE CONCRETO}

Relatório final de pesquisa de Iniciação Científica apresentado à Assessoria de PósGraduação e Pesquisa.

Orientação: Erika Regina Costa Castro

\section{BRASÍLIA}




\section{AGRADECIMENTOS}

Gostaríamos de agradecer especialmente aos nossos pais e irmãos, que nos incentivaram nesses momentos difíceis e compreenderam a nossa ausência enquanto nós nos dedicavamos à realização deste trabalho. Aos nossos amigos, Ana Laura Ulhoa, Caio Felipe, Davi Braz, Douglas, Gabriela Resende, Hildo Tavares, João Vitor, Jorrana Barros, Kamirã, Luca farias, Milena Creatani, Patricia Oliveira, Pedro Henrique, Rafaela Gomes, Regina Oliveira e Ricardo Brian, que sempre estiveram ao nosso lado, pela amizade incondicional e pelo apoio demonstrado ao longo de todo o período de tempo em que me dediquei a este trabalho. Aos professores, Jocinez Nogueira Lima, Nielsen José Dias Alves, Rosanna Duarte Fernandes Dutra e aos supervisores Leonardo Hylton e Rose Mary pelas correções e ensinamentos que nos permitiram apresentar um melhor desempenho no nosso processo de formação profissional ao longo do curso. Em especial, gostaríamos de agradecer a toda a orientação e auxilio que nos foi dado pela professora Erika Regina, que sempre esteve nos ajudando mesmo em momentos difíceis com muita dedicação, e a Elismeire que ao longo de toda a pesquisa esteve sempre disposta a nos auxiliar. 
"Não podemos resolver nossos problemas com o mesmo pensamento que tínhamos quando os criamos". Albert Einstein 


\section{RESUMO}

O cimento é um dos produtos mais importantes para o desenvolvimento do homem na idade moderna, porém sua produção traz uma série de problemas para o meio ambiente, sendo um dos grandes responsáveis pela emissão de dióxido de carbono (CO2) na atmosfera, um dos principais gases que provocam o aumento da temperatura na Terra. Outro produto que acarreta sérios problemas para o meio ambiente é a granalha de aço, que é utilizada comumente em jateamento, mas que após seu uso é descartada em aterros industriais ou utilizada para confecções de produtos. Um dos principais usos do cimento é na produção do concreto, mistura essa composta basicamente de água, cimento, agregado miúdo, agregado graúdo e aditivo, quando necessário. Dessa forma, utilizar granalha de aço como substituto parcial do cimento na produção do concreto em porcentagens especificas pode acarretar em um descarte mais sustentável do resíduo da granalha de aço e uma redução significativa da quantidade de cimento a ser usado, o que pode vir a reduzir a necessidade da produção deste insumo. Sendo assim, o presente trabalho se propôs a analisar o comportamento do concreto quando substituído parcialmente por resíduo de granalha de aço, utilizando ensaios de laboratório normatizados pela ABNT. Tendo em vista as proporções de substituição utilizadas, percebeu-se que os dados coletados foram muito próximos aos valores de referência realizados com os mesmos materiais e equipamentos, concluindo-se que o uso deste resíduo é viável tecnicamente e ambientalmente na produção de concreto, sendo um ótimo meio para um desenvolvimento mais sustentável.

Palavras-Chave: Reaproveitamento. Granalha de aço. Concreto. 
LISTAS DE FIGURAS, TABELAS, QUADROS, GRÁFICOS, SÍMBOLOS E ABREVIAÇÕES

Figura 1 - Corpos de provas com substituição 13

Figura 2-Misturador 15

$\begin{array}{ll}\text { Figura } 3 \text { - Aparelho de Vicat } & 16\end{array}$

Figura 4 - Aparelho de Vicat com a amostra utilizada para ensaio $\quad 17$

Figura 5 - Granalha de Aço $\quad 17$

$\begin{array}{ll}\text { Figura } 6 \text { - Agitador mecânico } & 18\end{array}$

Figura 7 - Frasco de Chapman com a granalha de aço já submersa no álcool 19

Figura 8 - Frasco Chapman com a amostra de areia submersa em água 20

Figura 9 - Areia normatizada segunda NBR 7214:2015 21

Figura 10 - Corpos de provas cilíndricos de $5 \times 10 \mathrm{~cm} \quad 22$

Figura 11 - Corpos de provas cilíndricos já moldados 23

Figura 12 - Corpos de provas cilíndricos submersos em água $\quad 24$

Figura 13 - Corpos de prova prismático moldado 24

Figura 14 - Mesa de adensamento $\quad 25$

Figura 15 - Corpos de provas cilíndricos moldados $\quad 25$

Figura 16 - Betoneira já com o concreto 26

Figura 17 - Slump Test $\quad 26$

Figura 18 - Concreto pós ensaio do slump test $\quad 27$

Figura 19 - Rompimento sob compressão axial 31

Figura 20 - Rompimento sob compressão diametral 34

Figura 21 - Momento exato do rompimento sob compressão diametral 34

Gráfico 1 - Compressão Axial CPII-Z 30

Gráfico 2 - Compressão Axial CPV-ARI 31

Gráfico 3 - Compressão diametral CPII-Z 33

Gráfico 4 - Compressão diametral CPV-ARI 34

Gráfico 5 - Flexão na tração CPII-Z 35

Gráfico 6 - Flexão na tração CPV-ARI 36

Tabela 1 - Caracterização da composição granulométrica segundo a NM 248:200 18

Tabela 2 - Quantidade de materiais utilizados 20

Tabela 3 - Traços ultilizados para confecção do concreto 23 
Tabela 4 - Ensaio de constistencia de pasta normal ultilizando o CPII-Z

Tabela 5 - Ensaio de constistencia de pasta normal ultilizando o CPV-ARI 25

Tabela 6 - Ensaio de tempo de pega ultilizando o CPII-Z 26

Tabela 7 - Ensaio de tempo de pega ultilizando CPV-ARI 26

Tabela 8 - Ensaio de granulometria da granalha de aço 26

Tabela 9 - Ensaio de granulometria da areia média lavada 28

Tabela 10 - Resultados de Compressão Axial do CPII-Z 29

Tabela 11 - Resultados de Compressão Axial do CPV-ARI 30

Tabela 12 - Resultados de Compressão Diametral do CPII-Z 32

Tabela 13 - Resultados de Compressão Diametral do CPV-ARI 33

Tabela 14 - Resultados de Tração na Flexão do CPII-Z 34

Tabela 15 - Resultados de Tração na Flexão do CPV-ARI 35

Tabela 16 - Resultados de compressão axial para o concreto 37

Tabela 17 - Resultados de compressão diametral para o concreto 38 


\section{SUMÁRIO}

1. INTRODUÇÃO 9

2. FUNDAMENTAÇÃO TEÓRICA 10

3. MÉTODO 13

3.1. Caracterização dos materiais 13

3.1.1. Cimento 13

3.1.1.1. Ensaio de pasta normal e tempo de pega 13

3.1.2. Granalha de aço 16

$\begin{array}{lll}\text { 3.1.2.1. } & \text { Módulo de finura granalha de aço } & 17\end{array}$

3.1.2.2. Massa especifica Granalha de aço $\quad 17$

3.1.3. Areia média lavada 18

$\begin{array}{lll}\text { 3.1.3.1. } & \text { Módulo de finura da areia } & 18\end{array}$

3.1.3.2. Massa específica da areia 19

$\begin{array}{lll}\text { 3.1.4. } & \text { Agregado graúdo } & 19\end{array}$

3.1.5. Agregado 21

3.2. Confecções dos corpos de prova 20

3.2.1. Corpos de prova cilíndricos 20

3.2.2. Corpos de prova prismáticos 22

3.3. Confecção dos corpos de prova de concreto 24

3.3.1. Moldagens dos corpos de prova com CPV 24

4. RESULTADOS E DISCUSSÃO 26

4.1. Tempo de pega 26

$\begin{array}{ll}\text { 4.2. Módulo de finura granalha de aço } & 27\end{array}$

4.2.1. Massa especifica Granalha de aço 28

4.3. Módulo de finura da areia média lavada 28

4.3.1. Massa específica da areia 29 
4.4. Rompimento dos corpos de prova cilíndricos a compressão axial

4.4.1. Compressão axial CPII-Z-32 30

4.4.2. Compressão axial CPV-ARI 31

4.5. Rompimento dos corpos de prova cilíndricos a compressão diametral 32

4.5.1. Compressão diametral CPII-Z-32 32

4.5.2. Compressão diametral do CPV-ARI 34

4.6. Ensaio de flexão para corpos de provas prismáticos 35

4.6.1. Ensaio de flexão para corpos de provas prismáticos moldados com CPII-Z-32 35

4.6.2. Ensaio de flexão para corpos de provas prismáticos moldados com CPV-ARI 36

4.7. Rompimento dos corpos de prova de concreto 37

4.7.1. Compressão axial corpos de prova de concreto $\quad 37$

4.7.2. Compressão diametral dos corpos de prova de concreto 38

5. CONSIDERAÇÕES FINAIS (OU CONCLUSÕES) 39

REFERÊNCIAS 


\section{INTRODUÇÃO}

O concreto é uma das misturas mais utilizadas na construção civil, sendo basicamente um composto de água, cimento, agregado miúdo, agregado graúdo e quando necessário aditivo.

Por sua vez, o cimento é o principal material na confecção de concreto sendo de vital importância para construções na sociedade moderna, porém sua produção e o seu descarte indevido trazem uma série de problemas para o meio ambiente. Sua produção e uso traz uma série de problemas para o meio ambiente, pois demanda que se tenha uma alta extração de matéria prima finita do meio ambiente e grande utilização de energia para sua produção, que acarreta na queima de combustíveis não renováveis, não somente contribuem para o esgotamento de matéria prima como também emitem gases nocivos como o $\mathrm{CO} 2$, que é um dos principais gases que provoca o aumento de temperatura na terra.

De acordo com uma matéria da "Columbia University", é estimado que as cimenteiras são responsáveis por um valor em torno de 5\% na emissão global de CO2. Todos esses problemas mobilizaram uma série de tentativas de reduzir os impactos negativos da produção de cimento no meio ambiente, seja por meio de formas mais sustentáveis de se utilizar a matéria prima, seja por meio do processo de produção industrial. (EARTH INSTITUTE, 2012)

Dentre os meios que vêm sendo utilizados na tentativa de minimizar os danos causados pelo uso e produção do cimento, está a utilização de materiais residuais de processos alheios ao do cimento, mas que possuam características físicas, químicas e mecânicas similares. Assim é possível atenuar dois cenários, um relacionado com a produção do cimento e outro com relação ao descarte de resíduos da construção civil, levando em conta que este, dentre os setores industriais, está entre os que mais geram resíduos sólidos.

O reaproveitamento de resíduos no ciclo produtivo da construção civil, é uma alternativa sustentável, para minimizar os impactos provenientes do descarte dos mesmos, além de poder reduzir os custos da obra.

No Brasil, têm se destacado pesquisas inovadoras, com grande atenção no reaproveitamento de resíduos no ciclo produtivo da construção civil, com o intuito de se 
verificar seu real desempenho, materiais como: pó de vidro, PET triturado, pó de mármore, resíduos de madeira, etc.

Dentre esses resíduos tem-se o reaproveitamento de subprodutos de minério de ferro. Segundo Aristimunho e Bertocini (2012) em seu artigo publicado na Revista IBRACON (2012), os autores realizaram diversos experimentos, a utilização de lama de minério de ferro em forma de pó como aditivo, substituindo parcialmente no cimento e também substituições no agregado miúdo, para confecção de concretos.

Outro produto que se relaciona com o minério de ferro é a granalha de aço, material esse que é utilizada como abrasivo em jateamento, para promover limpeza de superfícies removendo oxidação, modificando topografia de superfícies e outros benefícios.

A composição química da granalha de aço segue ao disposto na norma da SAE (Society of Automotive Engineers - EUA) Norma SAE J827 1.10.2019, que especifica uma porcentagem em peso no produto final de $0,80 \%$ a $1,20 \%$ de carbono, $0,60 \%$ a $1,20 \%$ de manganês, um mínimo de $0,40 \%$ de silício, um máximo de 0,05\% de enxofre e máximo de 0,05\% de fósforo. Componentes como o silício são conhecidos pela sua capacidade de dar resistência, fluidez e durabilidade ao concreto. (SINTO,2012)

Dessa forma, tendo em vista a composição química da granalha de aço ter propriedades que podem reforçar o desempenho do cimento na confecção de concreto, despertou-se a ideia de investigar se o uso do resíduo da granalha de aço contribui para o melhoramento da resistência mecânica do concreto, tendo em vista avaliar sua viabilidade como meio de reduzir a utilização de cimento, minimizando seus impactos ambientais e fornecer um descarte sustentável alternativo para a granalha de aço.

\section{FUNDAMENTAÇÃO TEÓRICA}

No artigo científico "Produção de cimento: Impactos à saúde e ao meio ambiente" desenvolvido por Maury e Blumenschein (2012), as autoras ressaltam que a indústria cimenteira é uma fonte poluidora, que causa impactos em todo o processo de preparo do cimento, ou seja, desde a britagem da pedra calcária até o ensacamento do produto.

A fase de extração da brita gera contaminação no solo e nos cursos d'água, em cavas abandonadas e nos assoreados, causando assim uma inviabilidade na agricultura. Diante disso, a reutilização/reaproveitamento de resíduos, substituindo parcialmente ou 
totalmente o cimento na confecção de argamassas ou concreto, está sendo uma das medidas tomadas pela construção civil a fim de diminuir os impactos ambientais causados pela produção do cimento.

Dentre os resíduos passíveis de serem utilizados na substituição do cimento, tem-se o resíduo de granalha de aço.

A granalha de aço é um material utilizado no jateamento abrasivo, que consiste em uma operação de tratamento de superfícies, ou seja, tal tratamento tem como função promover a limpeza da superfície, removendo todas as impurezas da mesma.

Tal material vem ganhando visibilidade na área de jateamento, pois quando comparado com os demais, ele apresenta diversas vantagens, como maior produtividade, menor custo de abrasivo por $\mathrm{M}^{2}$ limpo, melhor qualidade no trabalho, menor investimento em sistema de coletagem, entre outros, como se pode observar no "Estudo Comparativo de Custos e Rendimento Entre Granalha De Aço e Areia" realizado pela Cym Materiales S.A. (CYM MATERIALES, 2020)

A Revista IBRACON (2012) de Estruturas e Materiais publicou um artigo em que o tema analisado se assemelha ao tema deste estudo. Neste artigo Aristimunho e Bertocini (2012), fez uso de lama de minério de ferro em forma de pó como aditivo, substituição parcial do cimento e substituição total ou parcial na areia, para confecção de concreto.

No estudo de Aristimunho e Bertocini (2012) analisou-se três misturas: uma composição usando o pó de lama de minério de ferro como adição, nas porcentagens de 4\%, $6 \%, 8 \%$ e $20 \%$, uma usando como substituição no cimento, nas porcentagens de $10 \%, 20 \%$ e $30 \%$ e uma com substituição na areia nas porcentagens de $20 \%$, $60 \%$ e $100 \%$.

Após a realização dos ensaios, os autores chegaram à conclusão que as melhores dosagens foram as que utilizaram substituição de $100 \%$ da areia e a adição de $8 \%$. Ambas as dosagens apresentaram uma variação elevada quanto as suas resistências à compressão, quando comparada ao concreto convencional, os dados alcançados respectivamente foram de 36,98 Mpa e 34,56 Mpa, em comparação aos 24,36 Mpa alcançado pela mistura de referência, ambas com 90 dias.

A substituição de $100 \%$ da areia obteve o menor índice de densidade, se comparada os demais ensaios. As substituições do cimento pela lama de minério de ferro em pó obtiveram os piores resultados em todo o estudo, não sendo viável o seu uso segundo os autores. 
Um fator interessante verificado no experimento foi a coloração que os corpos de prova adquiriram. Ao adicionar pó de ferro, a coloração avermelhada envolveu todo o corpo de prova. Tal cor mudava de acordo com o teor de adição ou substituição, conforme pode ser observado na Figura 01.

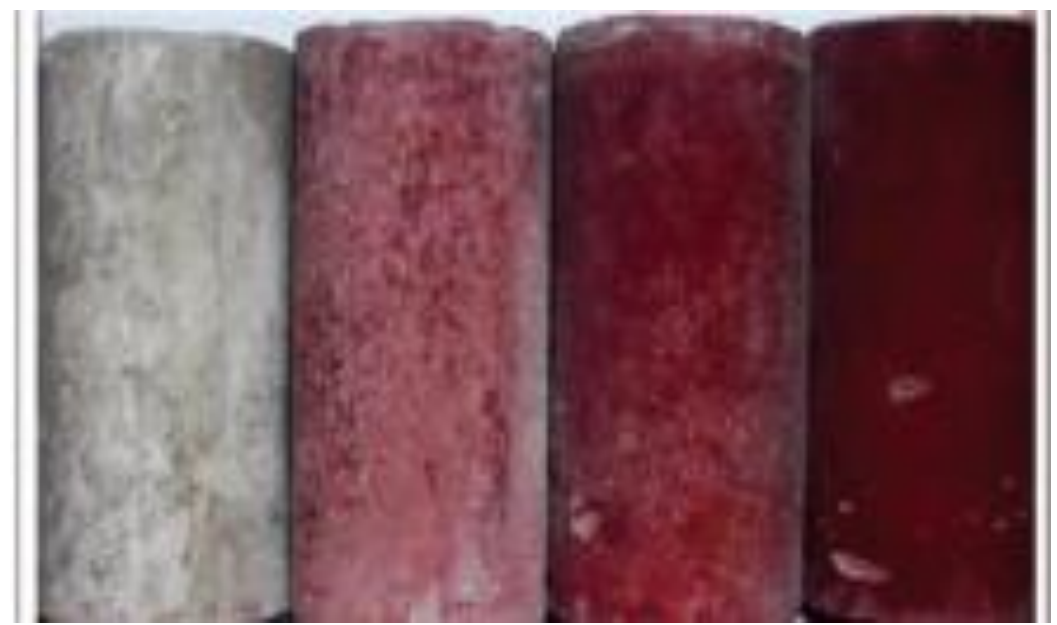

Figura 1 - Corpos de provas com substituição

Fonte : Aristimunho e Bertocini, 2012

Outra pesquisa realizada utilizando resíduos provenientes de metais, foi o artigo científico "Utilização de microesferas de aço nos concretos estruturais" desenvolvido por Cavalcante, Lopes e Batista (2002), eles estudaram a influência da utilização de microesferas de aço (granalha de aço) como agregado miúdo na confecção de concretos estruturais.

O referente artigo mostra a possibilidade de utilização desse resíduo como um novo material a ser incorporado nas misturas de concreto, visto que o mesmo apresenta características que podem conferir à mistura maior resistência mecânica, bem como maior massa específica, e possível utilização em concreto para uso em barragens.

A utilização de microesferas de aço, como agregado miúdo, com substituição de $33 \%$ a $50 \%$ da areia, apresentou resultados positivos, aumentando o valor da resistência de $8 \%$ a $20 \%$ quando comparado ao seu valor de referência.

$\mathrm{O}$ artigo concluiu que o concreto estudado, com o uso de microesferas de granalha de aço, pode ser utilizado em estruturas de contenção à gravidade, como muros de arrimos, barragens e até mesmo como estruturas de isolamentos radioativos. 


\section{MÉTODO}

Com a finalidade de determinar o desempenho da granalha de aço como substituta parcial na composição de concreto, fez-se necessário a realização de vários ensaios, que foram realizados no laboratório de solos e materiais do campus de Taguatinga II do UniCEUB.

No decorrer dos ensaios foram utilizados os seguintes materiais: cimento Portland CP II - Z 32 da marca Montes Claros; Cimento Portland CPV-ARI também da marca Montes Claros; areia média lavada; brita 0; Resíduo de granalha de aço.

Previamente foi definido que seriam utilizados 4 traços de mistura para que fosse realizada a caracterização da mistura, sendo o primeiro traço o com valor de referência, contendo assim $100 \%$ da sua quantidade de cimento, valor esse para servir de parâmetro de comparação para os outros traços. Para os 3 traços restantes foram utilizadas proporções de substituição no cimento por granalha de aço de $5 \%, 10 \%$ e $15 \%$

\subsection{Caracterização dos materiais}

Para se iniciar os experimentos fez-se necessário conhecer as características físicas e químicas dos materiais que seriam utilizados o que motivou uma série de experimentos com o objetivo de levantar dados de cada material.

\subsubsection{Cimento}

Para a realização dos ensaios, foram utilizados dois tipos de cimento, CP II Z (Cimento Portland composto com pozolana) e CPV-ARI (Cimento Portland de alta resistência inicial). Os cimentos utilizados seguem a norma NBR 16697/2018.

\subsubsection{Ensaio de pasta normal e tempo de pega}

Para realização do ensaio de tempo de pega foi utilizada NBR 16607:2018, que determina os procedimentos para determinação do tempo de pega. Para realização do ensaio foi pesado 500 gramas de cimento e através de tentativa e erro foi pesada a quantidade de água a ser utilizada na mistura.

Tendo a quantidade de cimento e de água devidamente pesada, os materiais foram colocados em um misturador mecânico (Figura 2), e permaneceram em repouso por 30 segundos, em seguida o misturador foi ligado em velocidade baixa por mais 30 segundos, seguido de 60 segundos de repouso sendo a primeira metade do repouso utilizada para remover a pasta que ficou presa nas laterais do recipiente de mistura e do misturador. Por 
fim, o misturador foi ligado em velocidade alta por um período de 60 segundos, finalizando a mistura.

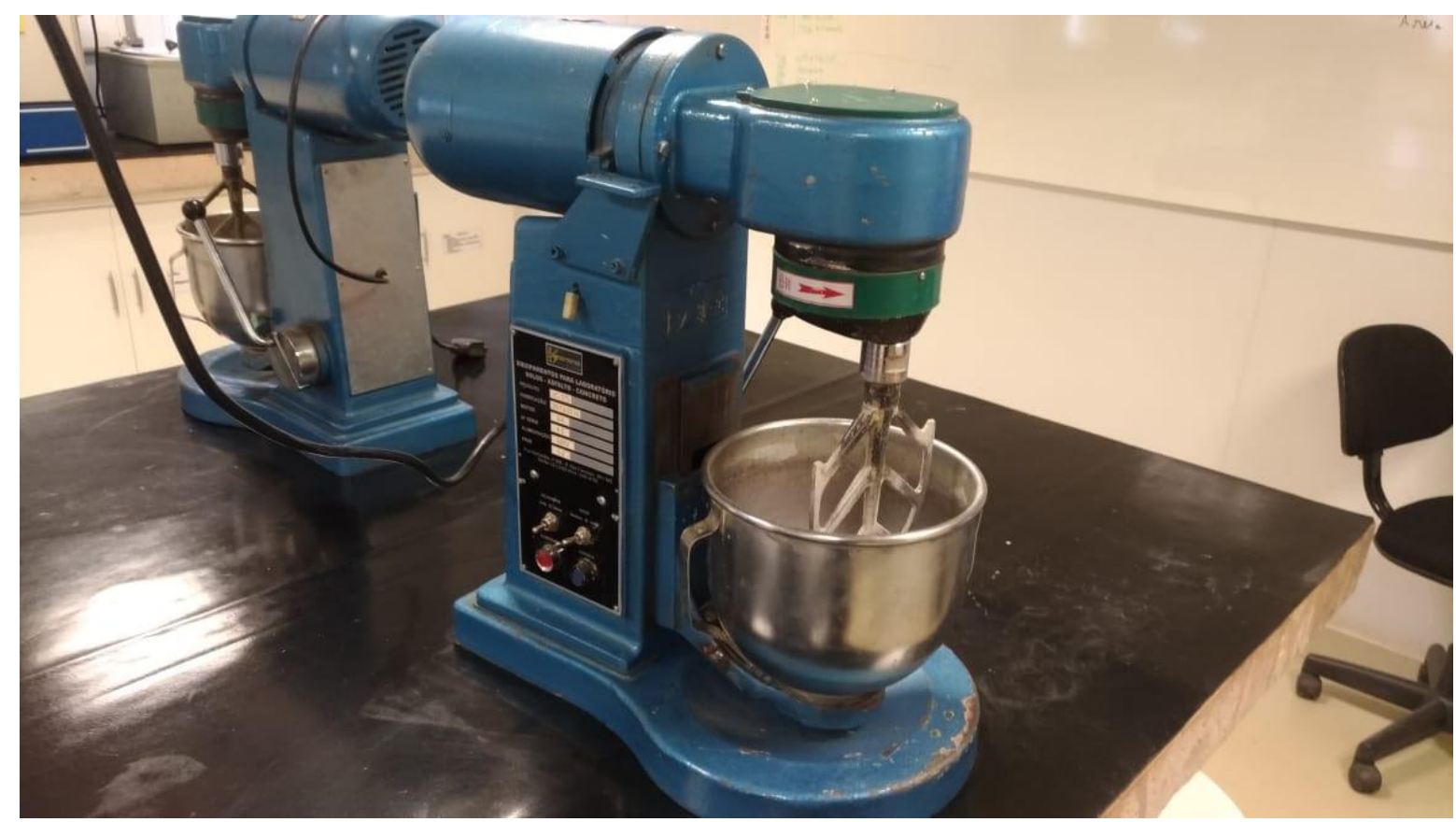

Figura 2 - Misturador

Fonte: Autores, 2020

Após a mistura realizada, um molde de plástico foi posicionado sobre uma placa de vidro e com o auxílio de uma concha o molde foi preenchido com a pasta, dando leve batidas ao lado para que a pasta de cimento se acomodasse no interior do molde de plástico, sendo nivelado no final com o auxílio de uma espátula.

Com o molde pronto, a pasta foi posicionada sob o aparelho de vicat (Figura 3) equipado no momento com a sonda de tetmajer, que permite determinar se a pasta está com consistência normal. Com o aparelho devidamente posicionado, a sonda é liberada de modo a penetrar na pasta e passando 30 segundos fazer uma leitura. Para a pasta ser classificada como normal, a leitura realizada ao final do ensaio deve ser de $6 \pm 1 \mathrm{~mm}$ da placa de vidro. Caso o valor não esteja de acordo deve ser dosada uma nova quantidade de água para se realizar o experimento. 


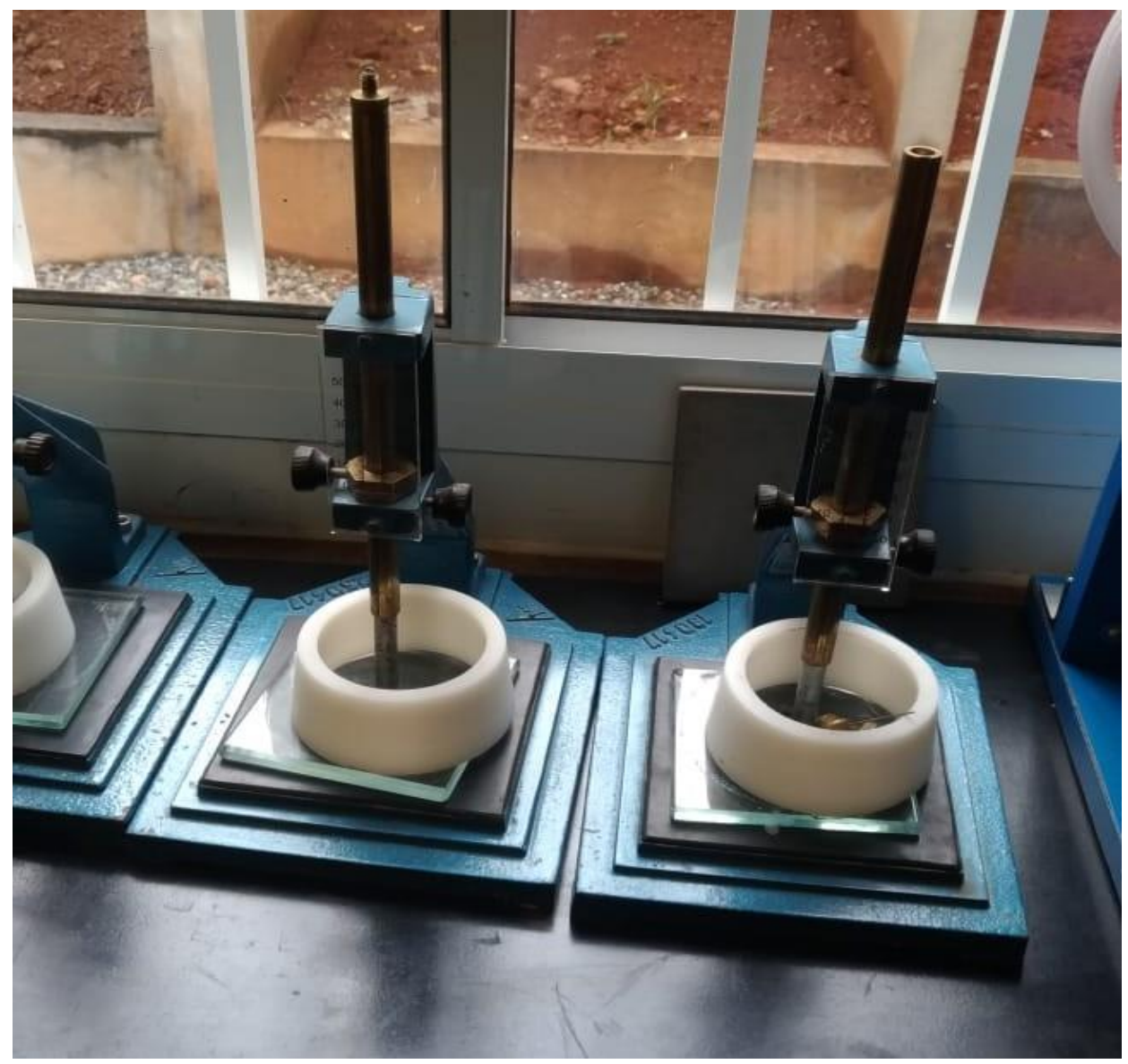

Figura 3 - Aparelho de Vicat

Fonte: Autores, 2020

Após várias tentativas ao achar o fator água cimento da pasta, a sonda de tetmajer foi substituída pela agulha de vicat, e tendo decorrido 30 minutos do período de moldagem deu-se início a determinação do tempo de pega. O molde foi posicionado sob o aparelho de vicat (Figura 4) e solta a agulha para que fosse medida a leitura, esse processo ocorreu em intervalos de 30 minutos, sendo que quando a amostra demonstrava alguma leitura os intervalos deveriam ser reduzidos, para não se perder o tempo exato do início da pega.

Após diversas tentativas obteve-se a leitura estabelecida por norma que é de $6 \pm 2$, anotando o tempo exato em que a leitura ocorreu. Tendo sido evidenciado o tempo de pega, o molde foi invertido para que se realizasse o ensaio de fim de pega.

A agulha do aparelho foi então substituída por uma específica de fim de pega e solta sobre o molde invertido até que não fosse mais possível observar nenhuma marca da agulha, anotando assim o tempo e que foi evidenciado o fim de pega. 


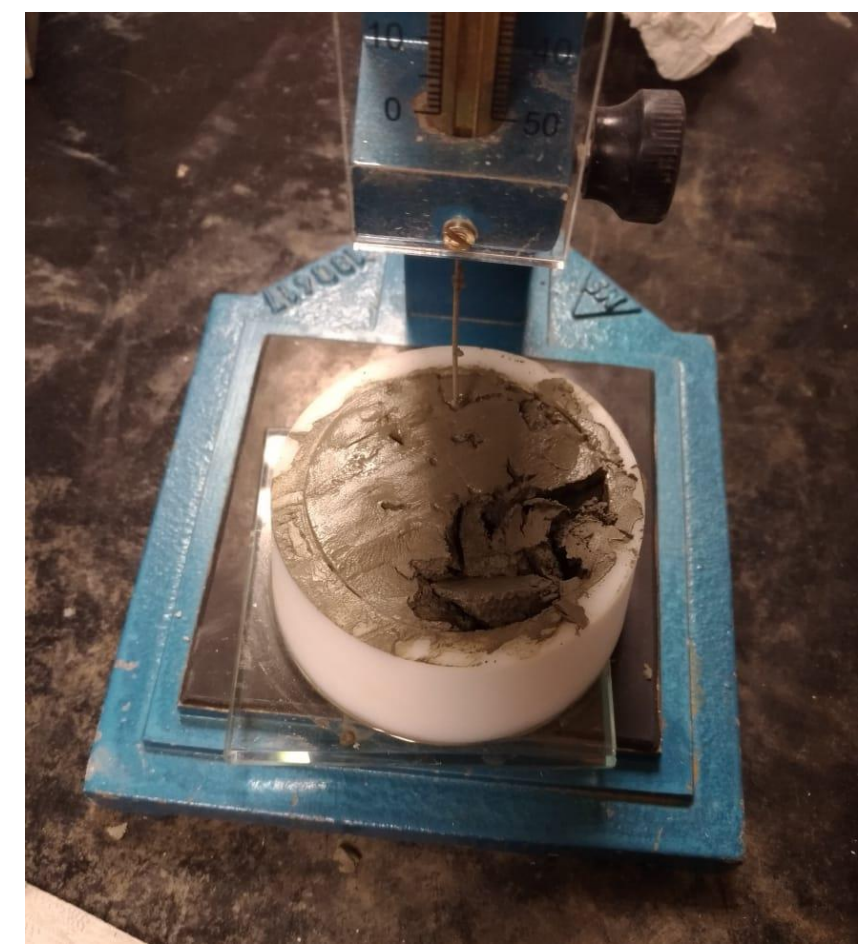

Figura 4 - Aparelho de Vicat com a amostra utilizada para ensaio

Fonte: Autores, 2020

Este ensaio foi realizado para cada um dos 4 traços e para cada um dos cimentos, anotando as diferenças entre cada um deles.

\subsubsection{Granalha de aço}

Para realização dos ensaios foi utilizado resíduo de granalha de aço, o qual foi adquirido em uma serralheria localizada em Taguatinga/DF (Figura 5), resíduo esse que foi caracterizado de acordo com a NBR NM 248:2003 e NBR 9776:1987, para determinação do módulo de finura e da massa específica.

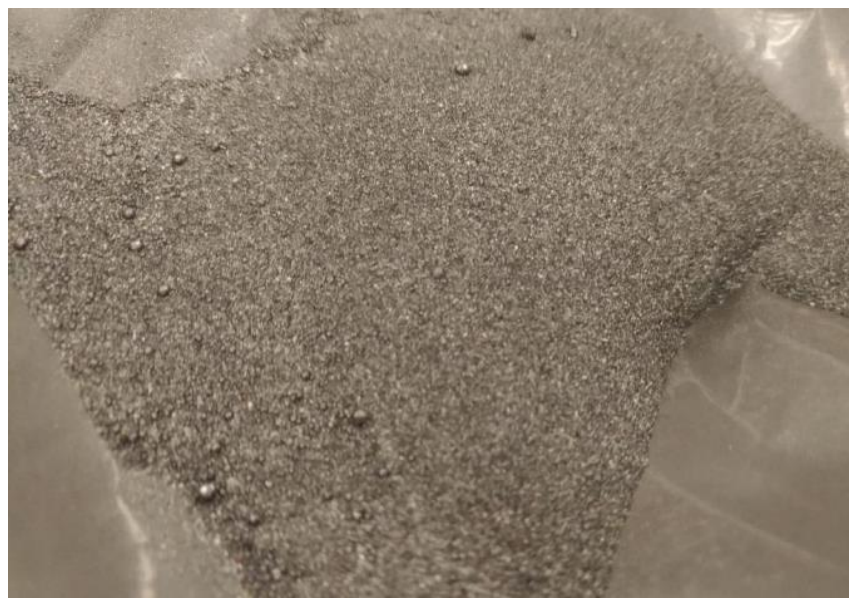

Figura 5 - Granalha de Aço

Fonte: Autores, 2020 


\subsubsection{Módulo de finura granalha de aço}

Na determinação do módulo de finura da granalha de aço, foi utilizada a norma NBR NM 248:2003- Agregados - Determinação da composição granulométrica, utilizada para agregados miúdos e agregados para concreto.

Primeiramente foram separadas as peneiras, conforme a norma citada. As mesmas foram limpas com o auxílio de uma escova e um pano úmido, a fim retirar as impurezas presentes de ensaios anteriores, evitando assim que houvesse qualquer contaminação nos resultados. Em seguida as peneiras foram empilhadas de acordo com a abertura da sua malha. Pesou se então uma amostra de $1000 \mathrm{~g}$ que foram colocadas na primeira peneira.

A amostra foi peneirada com o auxílio de um agitador mecânico (Figura 6) durante 10 minutos em velocidade constante. Passados os 10 minutos de mistura foram pesadas cada peneira para se anotar a quantidade de amostra que ficou retida.

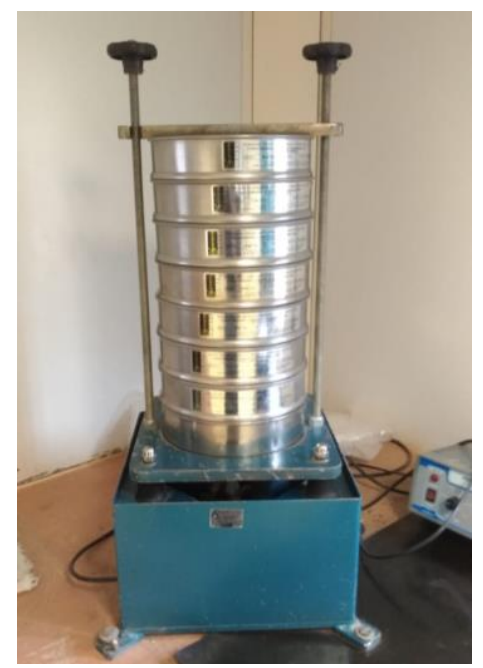

Figura 6 - Agitador mecânico

Fonte: Autores, 2020

3.1.3.1. Massa específica Granalha de aço

Para realização do ensaio de massa específica utilizando granalha de aço foi utilizado a norma NBR 9776:1987. O ensaio consiste em utilizar o frasco de Chapman (Figura 7), para determinar a massa específica do agregado miúdo, o frasco é composto de dois bulbos e de um gargalo graduado.

Foi então realizado o ensaio com a granalha. Colocou-se a água até a marca do frasco e adicionado 500 gramas de granalha, em seguida foi dado por 3 minutos leves pancadas no fundo do frasco para remover as bolhas de ar existentes e em seguida observado o volume ocupado. 
Tendo em vista a alta densidade do material não foi possível obter a leitura e como solução foi utilizado álcool na solução ao invés de água, foram então repetidos os procedimentos o que possibilitou a obtenção do valor da massa específica.

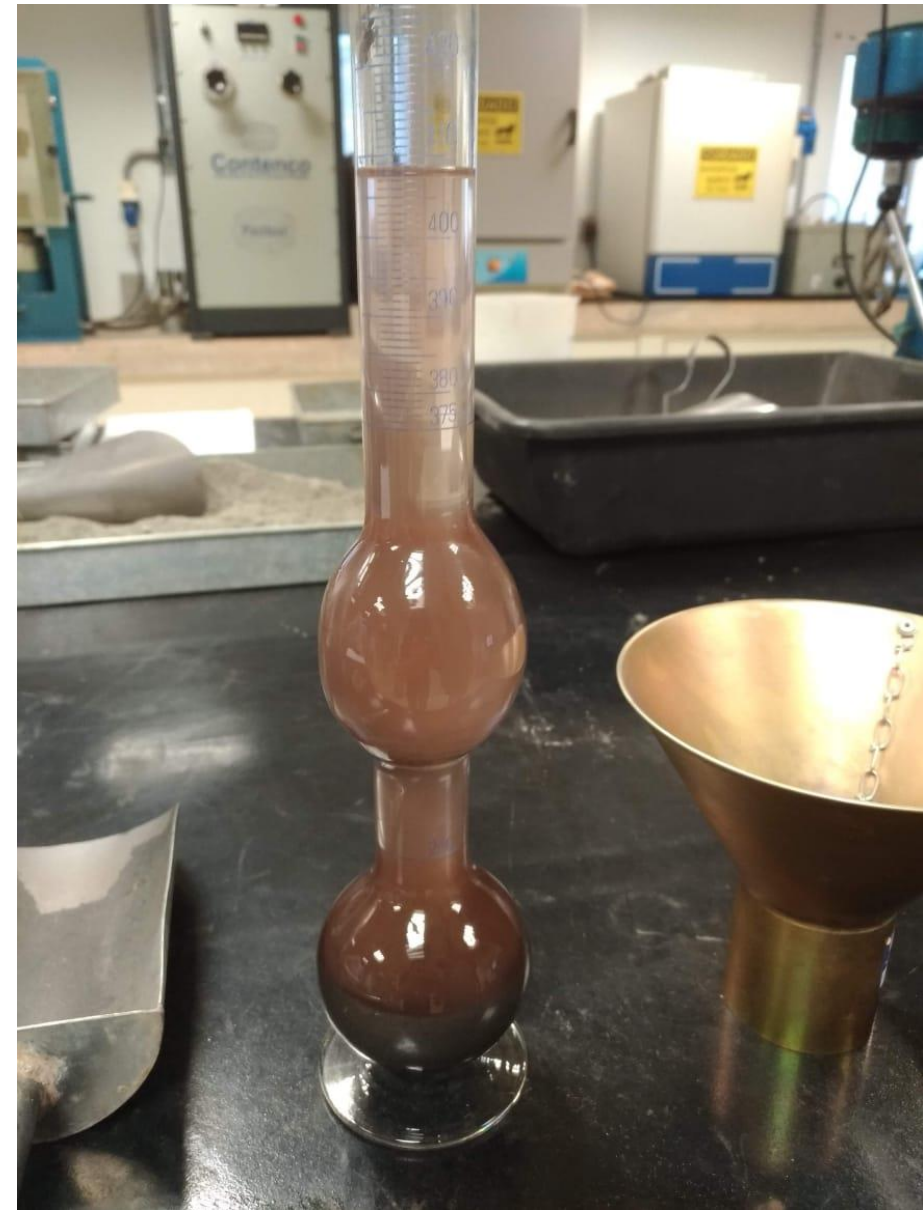

Figura 7 - Frasco de Chapman com a granalha de aço já submersa no álcool

Fonte: Autores, 2020

\subsubsection{Areia média lavada}

Nos ensaios foi utilizada areia média lavada ensacada obtida em uma loja de construção. A areia, assim como a granalha, foi caracterizada de acordo com a NBR NM 248:2003 e NBR 9776:1987, para determinação do módulo de finura e da massa específica.

\subsubsection{Módulo de finura da areia}

Tal como a granalha de aço, foram realizados todos os procedimentos exigidos pela norma NBR NM 248:2003, possibilitando a obtenção dos resultados almejados. 


\subsubsection{Massa específica da areia}

Seguindo a norma NBR 9776:1987, foi utilizado o frasco de Chapman junto a 500 gramas de areia (Figura 8). Para realização do ensaio foi adicionado água até a marcação no frasco e em seguida adicionado os 500 gramas de areia, após isso foi dado por 3 minutos leves pancadas na base do frasco para remover as bolhas de ar existentes e em seguida observado o volume ocupado.

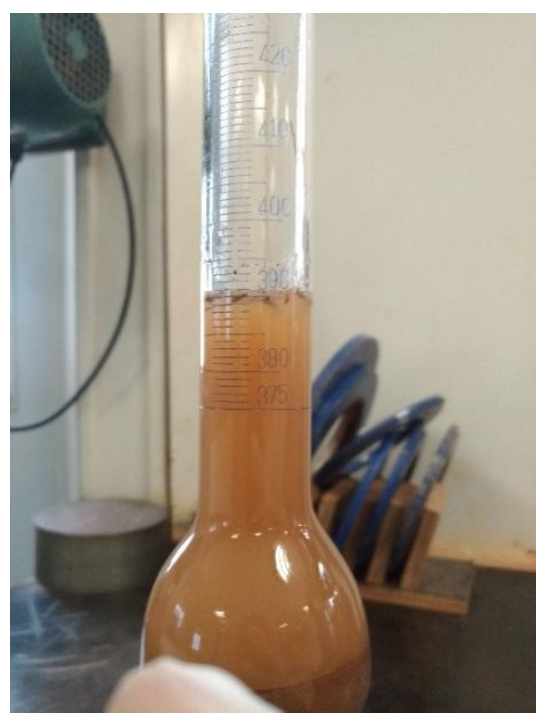

Figura 8 - Frasco Chapman com a amostra de areia submersa em água

Fonte: Autores, 2020

\subsubsection{Agregado graúdo}

A caracterização do agregado graúdo seguiu a mesma metodologia utilizada para a determinação da composição granulométrica da areia. Diante dos resultados, o agregado graúdo utilizado (Tabela 1) foi classificado como brita 0.

De acordo com a NBR 7211:2009 - Agregados para concreto - Especificação, cada tipo de brita proporciona ao concreto desempenhos e usos diferentes. Devido às dimensões da brita 0 , tal britagem é muito utilizada na produção de vigas, vigotas, lajes, blocos de concreto. 
CARACTERIZAÇÃO BRITA 0

\begin{tabular}{|c|c|c|c|c|c|c|}
\hline \multicolumn{7}{|c|}{ COMPOSIÇÃO GRANULOMÉTRICA } \\
\hline $\begin{array}{c}\text { Peneira } \\
(\mathbf{m m})\end{array}$ & $\begin{array}{c}\text { Massa da } \\
\text { peneira Vazia } \\
(\mathrm{g})\end{array}$ & $\begin{array}{c}\text { Massa da } \\
\text { Amostra }+ \\
\text { Peneira (g) }\end{array}$ & $\begin{array}{c}\text { Massa } \\
\text { Amostra (g) }\end{array}$ & $\begin{array}{c}\% \\
\text { Retida }\end{array}$ & $\begin{array}{c}\text { \% Retida } \\
\text { corrigida }\end{array}$ & $\begin{array}{c}\% \text { Retida } \\
\text { acumulada }\end{array}$ \\
\hline $\mathbf{1 2 , 5}$ & 355,75 & 361,8 & 30,25 & $2,017 \%$ & $2,02 \%$ & $2,017 \%$ \\
\hline $\mathbf{9 , 5}$ & 365,28 & 371,7 & 849,08 & $56,605 \%$ & $56,61 \%$ & $58,622 \%$ \\
\hline $\mathbf{6 , 3}$ & 319 & 532,64 & 506,97 & $33,798 \%$ & $33,80 \%$ & $92,420 \%$ \\
\hline $\mathbf{4 , 8}$ & 314,2 & 909,3 & 595,10 & $59,510 \%$ & $59,51 \%$ & $151,930 \%$ \\
\hline $\mathbf{4 , 8}$ & 304,25 & 463,8 & 59,49 & $3,966 \%$ & $3,97 \%$ & $96,386 \%$ \\
\hline Fundo & $\mathbf{3 1 6 , 7 4}$ & $\mathbf{3 3 6 , 2 5}$ & $\mathbf{5 2 , 7 7}$ & $\mathbf{3 , 5 1 8 \%}$ & $3,52 \%$ & $99,904 \%$ \\
\hline \multicolumn{7}{|c|}{} \\
\hline
\end{tabular}

Tabela 1 - Caracterização da composição granulométrica segundo a NM 248:2003

Fonte: Autores, 2020

\subsubsection{Agregado normatizado}

Para realização dos ensaios de caracterização da mistura, foi utilizada areia normatizada (Figura 9) pela NBR 7214:2015.

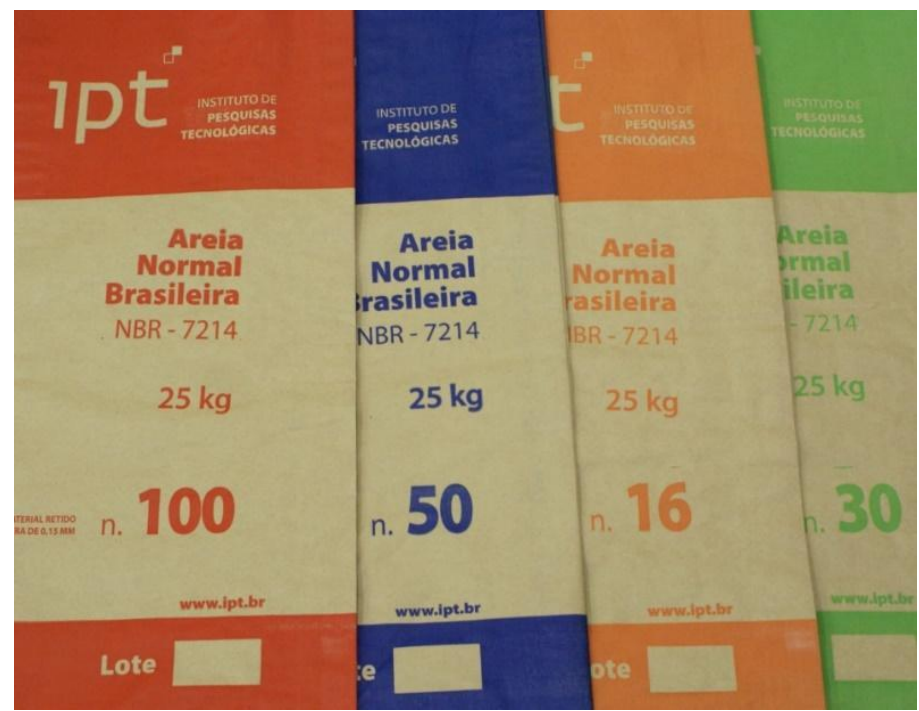

Figura 9 - Areia normatizada segunda NBR 7214:2015

Fonte: $\underline{\text { http://www.ipt.br/noticias interna.php?id noticia=191 }}$

\subsection{Confecção dos corpos de prova}

Para realização dos ensaios de resistência mecânica a compressão, a tração e a tração na flexão foram confeccionados uma série de corpos de prova para serem rompidos com 3, 7 e 28 dias, cada um seguindo sua respectiva norma.

\subsubsection{Corpos de prova cilíndricos}

Para a moldagem dos corpos de prova cilíndricos (Figura 10) foi utilizada a NBR 7215:2019 que especifica o método de preparo e a quantidade de areia de acordo com sua 
finura. Foram produzidos corpos de prova para 04 traços diferentes: um traço de referência (100\% cimento) e 03 traços com porcentagens de 5\%, 10\% e 15\% de substituição do cimento por resíduo de granalha de aço.

Primeiramente foram separados os moldes para receber a massa, aplicando neles uma fina camada de óleo, para facilitar a desmoldagem, evitando assim que eles se danifiquem.

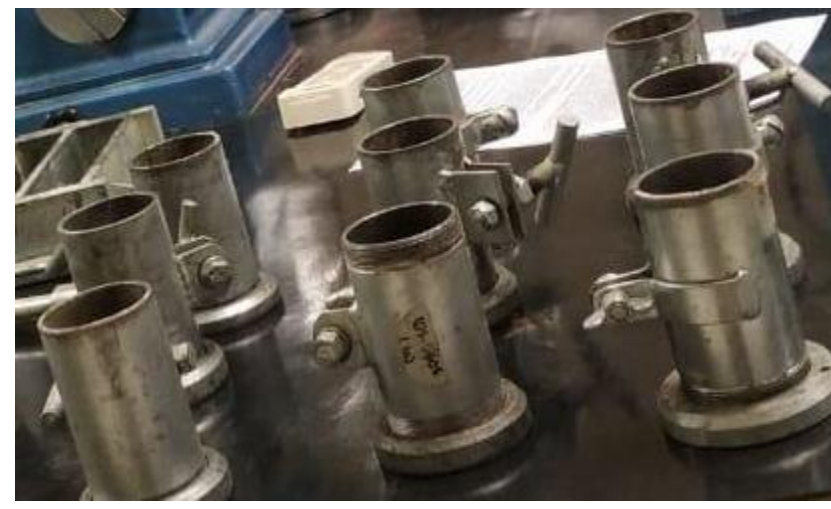

Figura 10 - Corpos de provas cilíndricos de $5 \times 10 \mathrm{~cm}$

Fonte: Autores, 2020

Os materiais utilizados para confecção dos corpos de prova, foram separados de acordo com a norma, sendo 624 gramas de cimento, 300 gramas de água e 468 gramas de cada fração da areia normatizada, conforme pode ser verificado na Tabela 2.

\begin{tabular}{|c|c|}
\hline \multicolumn{1}{|c|}{ Material } & Massa para a mistura (g) \\
\hline Cimento Portland & $624 \pm 0,4$ \\
\hline Água & $300 \pm 0,2$ \\
\hline Areia normal & 0 \\
\hline Fração grossa & $468 \pm 0,3$ \\
\hline Fração média grossa & $468 \pm 0,3$ \\
\hline Fração média fina & $468 \pm 0,3$ \\
\hline Fração fina & $468 \pm 0,3$ \\
\hline
\end{tabular}

Tabela 2 - Quantidade de materiais utilizados

Fonte: Autores, 2020

Com todos os materiais separados e os moldes cilíndricos devidamente lubrificados, foi dado início homogeneização mecânica dos materiais. Primeiramente foi adicionado no recipiente o cimento e a água, ligando o misturador em velocidade baixa por 30 segundos. Passado esse tempo inicial foi adicionado durante 30 segundos todas as frações de areias que foram previamente pesadas, findados os 30 segundos o misturador foi colocado em velocidade alta por um período de também 30 segundos. 
Passado esse processo o misturador foi desligado, e no decorrer de 1 minuto e 30 segundos a massa foi colocada em repouso, sendo que nos primeiros 15 segundos foi utilizada uma espátula para realizar a limpeza das bordas do recipiente. Por fim o misturador foi ligado em velocidade alta por um período de 1 minuto.

Com a massa pronta, os corpos de prova foram preenchidos com o auxílio de um funil, em quatro camadas de massa, cada camada recebendo 30 golpes com um soquete padronizado, para realizar o adensamento, por fim o excesso foi removido com o auxílio de uma espátula.

Foram moldados ao todo 48 corpos de prova cilíndricos (Figura 11), 24 confeccionados com CPII-Z 32 e 24 com CPV-ARI, sendo 6 para referência, 6 para 5\%, 6 para 10\% e 6 para 15\%. Para cada idade (3, 7 e 28 dias, sendo) foram utilizados 2 CP, sendo cada um de um tipo de cimento específico (01 para CP II Z e 01 para CP V), sendo 1 corpo de prova para compressão axial e 1 corpo de prova para compressão diametral.

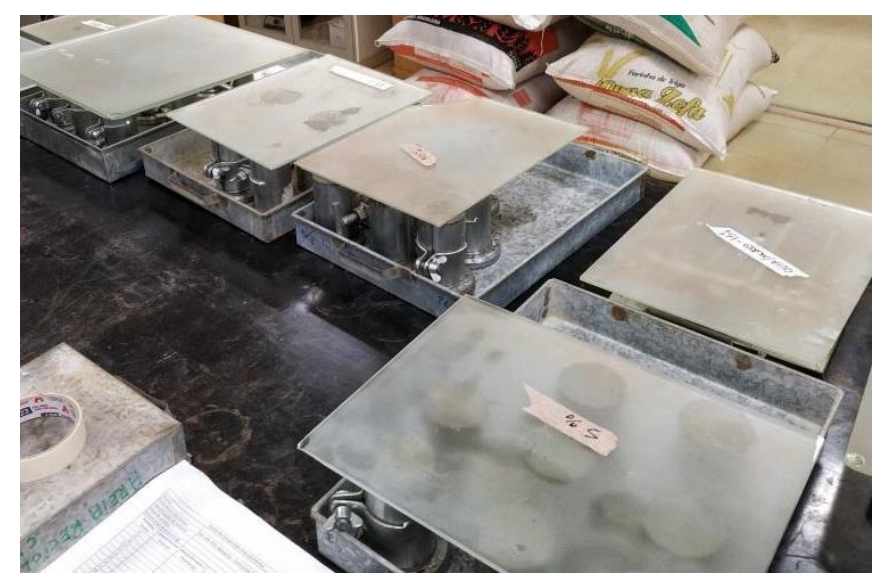

Figura 11 - Corpos de provas cilíndricos já moldados

Fonte: Autores, 2020

Após 24 horas da moldagem dos corpos de prova, foram colocados em cura submersa (Figura 12) para serem rompidos nas idades de 3, 7 e 28 dias. 


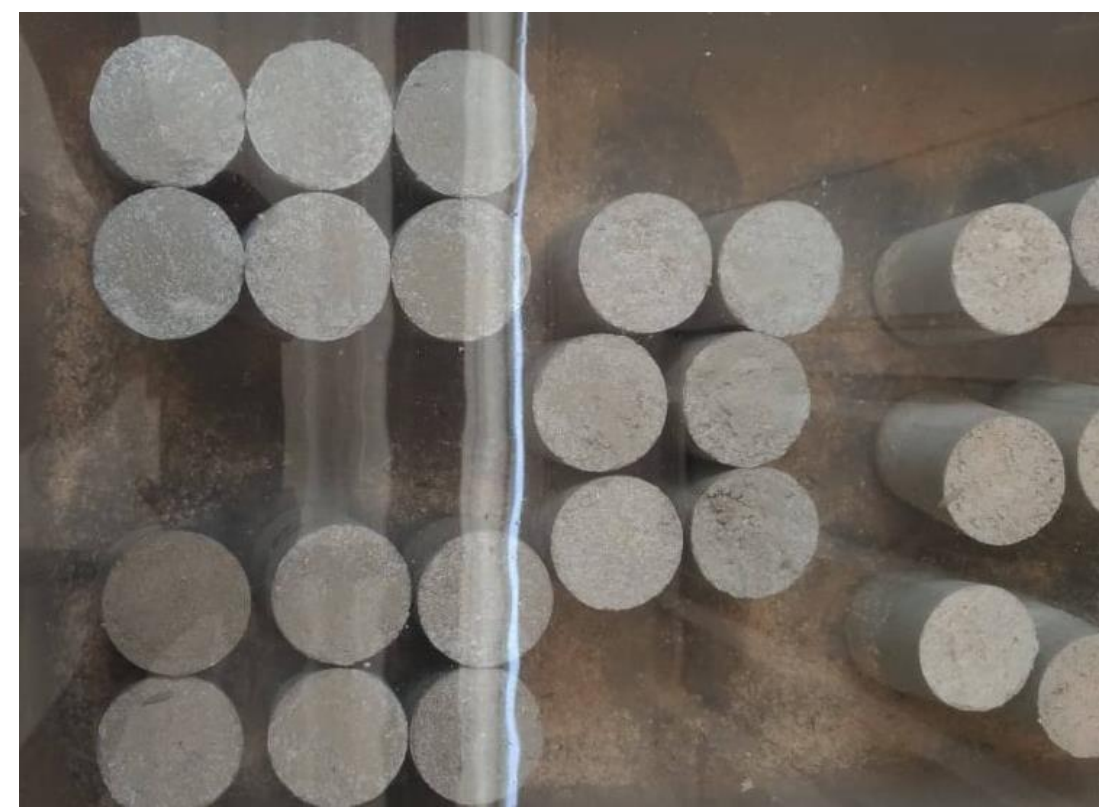

Figura 12 - Corpos de provas cilíndricos submersos em água

Fonte: Autores, 2020

\subsubsection{Corpos de prova prismáticos}

Inicialmente foi pincelada uma fina camada de óleo nos moldes dos corpos prismáticos, para evitar que os corpos de prova se danifiquem no processo de desmoldagem. Com os moldes preparados seguiu-se o mesmo processo de preparação de massa para os corpos de prova cilíndricos.

Com a massa preparada, foi colocado no molde prismático duas camadas de massa (Figura 13), sendo cada uma delas adensada com o auxílio de uma mesa de adensamento (Figura 14) que desfere pancadas que ajudam a adensar a massa no recipiente. Realizado o adensamento, os corpos de prova foram nivelados com auxílio de uma espátula. Os corpos de prova prismáticos foram desmoldados após 48 horas da sua confecção.

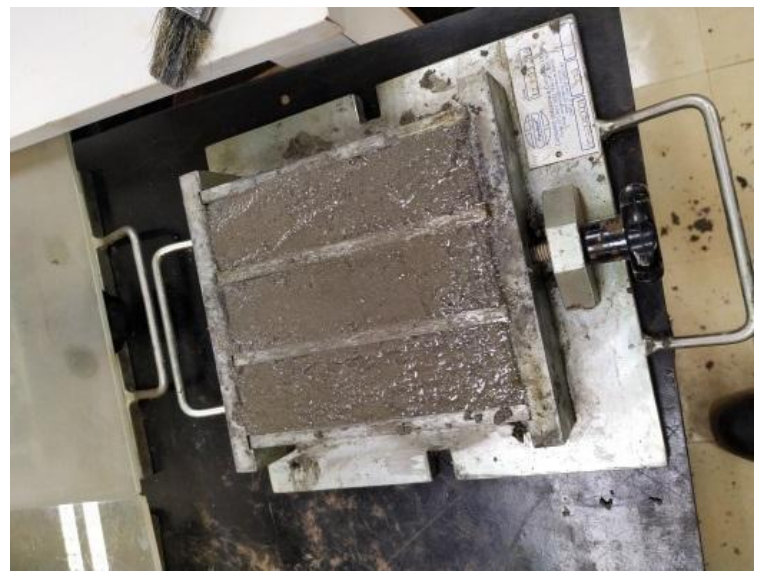

Figura 13 - Corpos de prova prismático moldado Fonte: Autores, 2020 


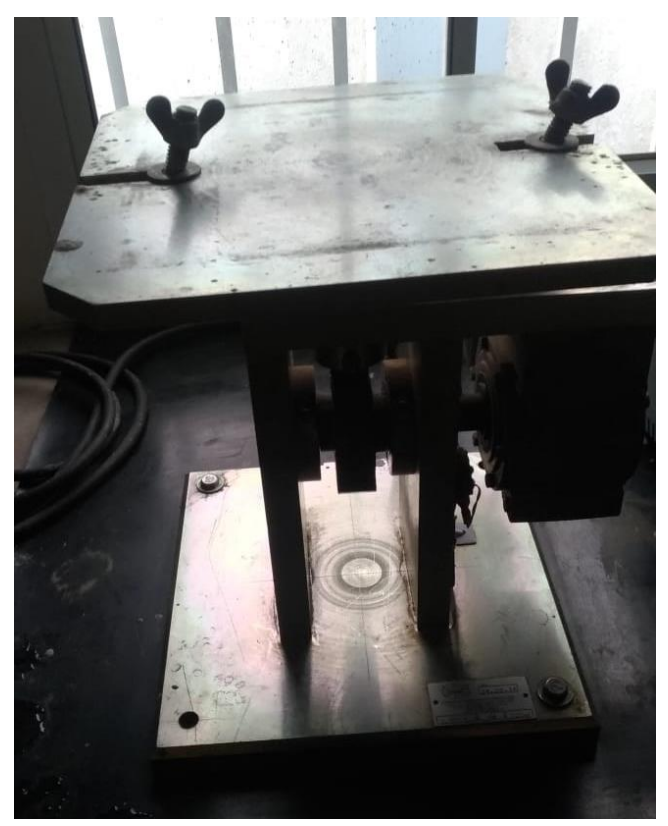

Figura 14 - Mesa de adensamento

Fonte: Autores, 2020

Foram moldados ao todo 68 corpos de prova prismáticos (Figura 15) , 36 foram confeccionadas com CPII-Z 32 e 36 com CPV-ARI, sendo que 9 para referência, 9 para 5\%, 9 para 10\% e 9 para 15\%, os quais foram rompidos 3 CP em cada idade, ou seja, 3, 7 e 28 dias.

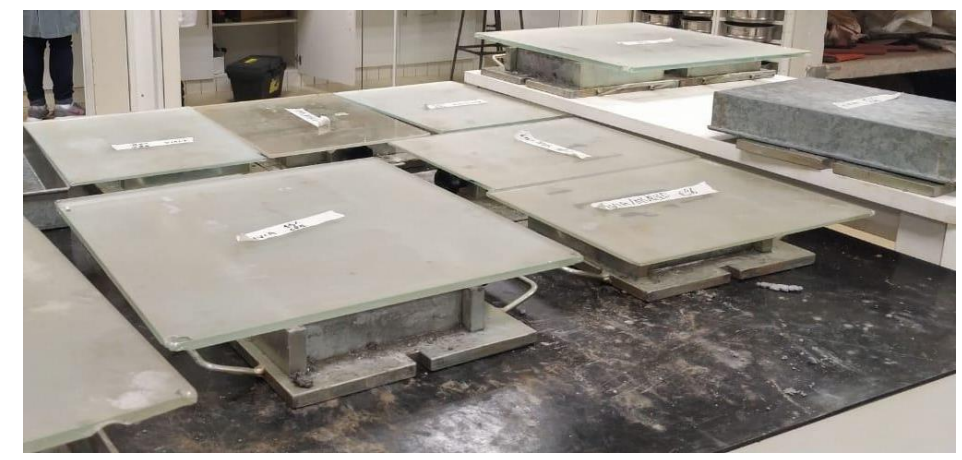

Figura 15 - Corpos de provas cilíndricos moldados

Fonte: Autores, 2020

\subsection{Confecção dos corpos de prova de concreto}

Com os resultados obtidos na elaboração dos corpos de prova utilizando areia normatizada, optou-se em utilizar 4 traços para elaboração dos corpos de prova de concreto, sendo eles o primeiro de referência, utilizando $100 \%$ do cimento, e o restante de $5 \%, 15 \%$ e $20 \%$.

3.3.1. Moldagens dos corpos de prova com CPV

Para realizar a moldagem dos corpos de prova de concreto, foi definido os traços (Tabela 3) a serem utilizados, sendo seu fator água cimento descoberto por meio do ensaio 
de slump test de acordo com a NBR NM 67:1998, que consiste em avaliar o abatimento de uma determinada quantidade de concreto.

\begin{tabular}{c|c}
\hline Substituição & Traço Unitário \\
\hline $0 \%$ & $1: 1,095: 2,19: 0,527$ \\
\hline $5 \%$ & $1: 1,095: 2,19: 0,498$ \\
\hline $15 \%$ & $1: 1,095: 2,19: 0,443$ \\
\hline $20 \%$ & $1: 1,095: 2,19: 0,408$ \\
\hline
\end{tabular}

Tabela 3 - Traços utilizados para confecção do concreto

Fonte: Autores, 2020

Com os valores dos traços definidos, deu se início a confecção do concreto com o auxílio da betoneira (Figura 16). Seguindo a metodologia já descrita, os moldes dos corpos de prova de concreto foram previamente pincelados com óleo para evitar que eles se danifiquem no processo de desmoldagem. Antes de serem moldados foi novamente realizado o slump test (Figura 17 e 18) para confirmar que o traço estava de acordo com os valores esperados para a mistura.

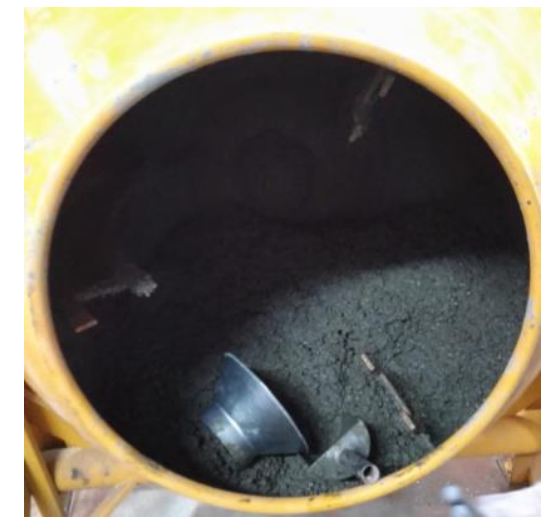

Figura 16 - Betoneira já com o concreto

Fonte: Autores, 2020

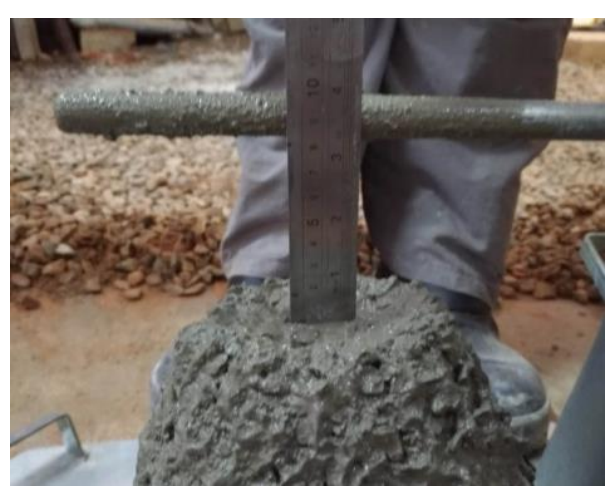

Figura 17 - Slump Test

Fonte: Autores, 2020 


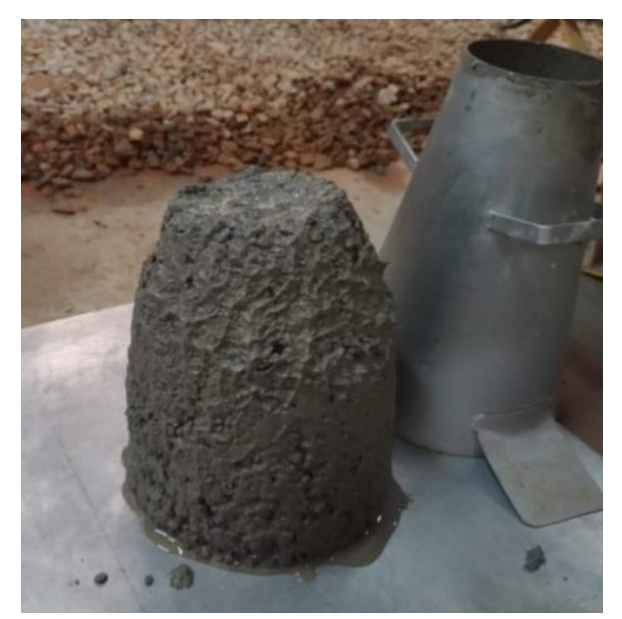

Figura 18 - Concreto pós ensaio do slump test

Fonte: Autores, 2020

Foram confeccionados ao todo 60 corpos de prova utilizando o cimento CPV-ARI, sendo 15 deles para cada um dos traços utilizados, ou seja, 15 corpos de prova para os de referência, 15 para os de 5\%, 15 para os de $10 \%$ e 15 para os de $15 \%$. Dentre os 15 reservados para cada traço 3 foram moldados para serem rompidos com 1 dia de cura úmida, 3 para serem rompidos com 3 dias de cura úmida, 3 para 7 dias de cura úmida, 3 para 28 dias e 3 para 90 dias.

\section{RESULTADOS E DISCUSSÃO}

\subsection{Tempo de pega}

Após diversas tentativas realizadas para cada traço de cada cimento seguindo a norma NBR 16607:2018, foram obtidos os valores referentes a consistência de pasta normal tanto para o CPII-Z-32 (Tabela 4) como para o CPV-ARI (Tabela 5).

Ensaio de consistência de pasta normal (CPII-Z)

\begin{tabular}{|c|c|c|c|c|}
\hline Corpo de prova & \multicolumn{1}{c}{$\begin{array}{c}\text { Massa do } \\
\text { cimento } \\
\mathbf{( g )}\end{array}$} & $\begin{array}{c}\text { Massa } \\
\text { do pó } \\
\text { de ferro } \\
\mathbf{( g )}\end{array}$ & $\begin{array}{c}\text { Massa } \\
\text { da água } \\
\text { utilizada } \\
\mathbf{( g )}\end{array}$ & $\begin{array}{c}\text { Quantidade de } \\
\text { água para a } \\
\text { consistência } \\
\text { normal } \\
\mathbf{( \% )}\end{array}$ \\
\hline Referência & 500 & 0 & 136 & $27,200 \%$ \\
\hline $\mathbf{5 \%}$ & 475 & 25 & 131,25 & $26,250 \%$ \\
\hline $\mathbf{1 0 \%}$ & 450 & 50 & 123,5 & $24,700 \%$ \\
\hline $\mathbf{1 5 \%}$ & 425 & 75 & 118 & $23,600 \%$ \\
\hline
\end{tabular}

Tabela 4 - Ensaio de consistência de pasta normal utilizando o CPII-Z 
Ensaio de consistência de pasta normal (CPV-ARI)

\begin{tabular}{|c|c|c|c|c|}
\hline Corpo de prova & \multicolumn{1}{c}{$\begin{array}{c}\text { Massa do } \\
\text { cimento } \\
\mathbf{( g )}\end{array}$} & $\begin{array}{c}\text { Massa } \\
\text { do pó } \\
\text { de ferro } \\
\mathbf{( g )}\end{array}$ & $\begin{array}{c}\text { Massa } \\
\text { da água } \\
\text { utilizada } \\
\mathbf{( g )}\end{array}$ & $\begin{array}{c}\text { Quantidade de } \\
\text { água para a } \\
\text { consistência } \\
\text { normal } \\
\mathbf{( \% )}\end{array}$ \\
\hline Referência & 500 & 0 & 145 & $29,000 \%$ \\
\hline $\mathbf{5 \%}$ & 475 & 25 & 137,5 & $27,500 \%$ \\
\hline $\mathbf{1 0 \%}$ & 450 & 50 & 132,25 & $26,450 \%$ \\
\hline $\mathbf{1 5 \%}$ & 425 & 75 & 126,25 & $25,250 \%$ \\
\hline
\end{tabular}

Tabela 5 - Ensaio de consistência de pasta normal utilizando o CPV-ARI

Fonte: Autores, 2020

Sendo evidente que ao reduzir a quantidade de cimento pela substituição da granalha de aço a quantidade de água necessária para se obter a consistência de pasta normal também foi reduzida.

Realizado o ensaio de pasta normal, com o fator água cimento corrigido, foi analisado para ambos os cimentos seus respectivos início e fim de pega conforme as Tabelas 6 e 7

Ensaio de tempo de pega (CPII-Z)

\begin{tabular}{|c|c|c|c|c|c|}
\hline Corpo de prova & $\begin{array}{c}\text { Quantidade } \\
\text { de água para } \\
\text { a } \\
\text { consistência } \\
\text { normal } \\
(\%)\end{array}$ & Moldagem & $\begin{array}{l}\text { Início } \\
\text { da pega } \\
\text { (h) }\end{array}$ & $\begin{array}{c}\text { Fim da } \\
\text { pega } \\
\text { (h) }\end{array}$ & $\begin{array}{l}\text { Tempo de } \\
\text { pega } \\
\text { (h) }\end{array}$ \\
\hline Referência & $27,200 \%$ & $15: 15$ & $18: 30$ & $19: 05$ & $03: 50$ \\
\hline $5 \%$ & $26,250 \%$ & $14: 15$ & $16: 15$ & $18: 05$ & $03: 50$ \\
\hline $10 \%$ & $24,700 \%$ & $14: 30$ & $16: 40$ & $18: 20$ & $03: 50$ \\
\hline $15 \%$ & $23,600 \%$ & $14: 45$ & $17: 00$ & $18: 35$ & $03: 50$ \\
\hline
\end{tabular}

Fonte: Autores, 2020

\begin{tabular}{|c|c|c|c|c|c|}
\hline \multicolumn{6}{|c|}{ Ensaio de tempo de pega (CPV-ARI) } \\
\hline Corpo de prova & $\begin{array}{c}\text { Quantidade } \\
\text { de água para } \\
\text { a } \\
\text { consistência } \\
\text { normal } \\
(\%)\end{array}$ & Moldagem & $\begin{array}{c}\text { Início } \\
\text { da pega } \\
\text { (h) }\end{array}$ & $\begin{array}{c}\text { Fim da } \\
\text { pega } \\
\text { (h) }\end{array}$ & $\begin{array}{c}\text { Tempo de } \\
\text { pega } \\
\text { (h) }\end{array}$ \\
\hline Referência & $29,000 \%$ & 16:00 & 18:05 & 19:00 & 03:00 \\
\hline $5 \%$ & $27,500 \%$ & $16: 40$ & 19:15 & $20: 15$ & 03:35 \\
\hline $10 \%$ & $26,450 \%$ & 13:50 & $15: 50$ & $17: 10$ & 03:20 \\
\hline $15 \%$ & $25,250 \%$ & $14: 35$ & $17: 10$ & $17: 50$ & 03:15 \\
\hline
\end{tabular}


Analisando os resultados é possível perceber que o cimento CPII-Z 32, em todas as porcentagens analisadas, possui uma redução significativa no tempo entre o início e fim de pega. Quanto ao CPV-ARI é possível perceber que somente na porcentagem de $15 \%$ há redução na diferença de tempo entre o início e fim de pega.

4.2. Módulo de finura granalha de aço

Após realizada a pesagem de todas as peneiras, foi possível analisar a quantidade de material que ficou retido em cada uma delas, com esses valores foi possível criar a Tabela 8

Granulometria - Granalha de Aço

\begin{tabular}{|c|c|c|c|c|c|c|}
\hline $\begin{array}{c}\text { Peneira } \\
(\mathrm{mm})\end{array}$ & $\begin{array}{l}\text { Massa da } \\
\text { peneira } \\
\text { Vazia }(g)\end{array}$ & $\begin{array}{l}\text { Massa da } \\
\text { Amostra + } \\
\text { Peneira (g) }\end{array}$ & $\begin{array}{c}\text { Massa } \\
\text { Amostra } \\
(\mathrm{g})\end{array}$ & $\begin{array}{c}\% \\
\text { Retida }\end{array}$ & $\begin{array}{l}\% \text { Retida } \\
\text { corrigida }\end{array}$ & $\begin{array}{c}\% \text { Retida } \\
\text { acumulada }\end{array}$ \\
\hline 2,4 & 355,75 & 355,75 & 0 & $0,00 \%$ & & $0,00 \%$ \\
\hline 1,2 & 365,28 & 366,09 & 0,81 & $0,08 \%$ & & $0,08 \%$ \\
\hline 0,6 & 319 & 480,37 & 161,37 & $16,14 \%$ & & $16,22 \%$ \\
\hline 0,3 & 314,2 & 974,37 & 660,17 & $66,02 \%$ & & $82,24 \%$ \\
\hline 0,15 & 304,25 & 446,36 & 142,11 & $14,21 \%$ & & $96,45 \%$ \\
\hline Fundo & 316,74 & 350,92 & 34,18 & $3,42 \%$ & & $100 \%$ \\
\hline & Total & & 998,70 & $100 \%$ & & $100 \%$ \\
\hline \multicolumn{6}{|c|}{ MÓDULO DE FINURA } & 1,95 \\
\hline
\end{tabular}

Tabela 8 - Ensaio de granulometria da granalha de aço

Fonte: Autores, 2020

A Tabela 8 mostra como o resíduo de granalha de aço é graduado. Com os dados obtidos foi possível obter a porcentagem de material retido em cada peneira e como consequência obter o valor da porcentagem retida acumulada, valor esse que por intermédio da fórmula, foi possível obter o módulo de finura do resíduo.

$$
M F=\frac{\sum \% \text { retida acumulada }}{100}
$$

\subsubsection{Massa específica Granalha de aço}

Com a substituição da água por álcool, mantendo-se as $500 \mathrm{~g}$ de granalha de aço, foi necessário realizar algumas mudanças no processo de formulação o que gerou a equação a seguir.

$$
m=\frac{500}{L-276,15}
$$


Com a fórmula adaptada para se obter a massa específica do resíduo de granalha de aço, foi possível calcular os resultado do experimento, que foi realizado duas vezes para fins de qualidade, os resultados podem ser observados a seguir.

$$
\begin{gathered}
m 1=\frac{500}{407-276,15} \\
m 1=3,82116928 \frac{\mathrm{g}}{\mathrm{cm}^{3}} \\
m 2=\frac{500}{408-276,15} \\
m 2=3,792188093 \mathrm{~g} / \mathrm{cm}^{3}
\end{gathered}
$$

\subsection{Módulo de finura da areia média lavada}

Seguindo as especificações da NBR NM 248:2003, foi possível de maneira similar ao processo realizado com o resíduo de granalha de aço, realizar o ensaio de granulometria da

\begin{tabular}{|c|c|c|c|c|c|c|}
\hline $\begin{array}{c}\text { Peneira } \\
(\mathrm{mm})\end{array}$ & $\begin{array}{l}\text { Massa da } \\
\text { peneira } \\
\text { Vazia }(g)\end{array}$ & $\begin{array}{c}\text { Massa da } \\
\text { Amostra + } \\
\text { Peneira (g) }\end{array}$ & $\begin{array}{c}\text { Massa } \\
\text { Amostra } \\
(\mathrm{g})\end{array}$ & $\begin{array}{c}\% \\
\text { Retida }\end{array}$ & $\begin{array}{l}\% \text { Retida } \\
\text { corrigida }\end{array}$ & $\begin{array}{l}\% \text { Retida } \\
\text { acumulada }\end{array}$ \\
\hline 2,4 & 355,75 & 361,8 & 6,05 & $0,605 \%$ & & $0,605 \%$ \\
\hline 1,2 & 365,28 & 371,7 & 6,42 & $0,642 \%$ & & $1,247 \%$ \\
\hline 0,6 & 319 & 532,64 & 213,64 & $21,364 \%$ & & $22,611 \%$ \\
\hline 0,3 & 314,2 & 909,3 & 595,10 & $59,510 \%$ & & $82,121 \%$ \\
\hline 0,15 & 304,25 & 463,8 & 159,55 & $15,955 \%$ & & $98,076 \%$ \\
\hline Fundo & 316,74 & 336,25 & 19,51 & $1,951 \%$ & & $100,027 \%$ \\
\hline \multicolumn{3}{|c|}{ Total } & 1000,30 & $100,0 \%$ & & $100,0 \%$ \\
\hline \multicolumn{6}{|c|}{ MÓDULO DE FINURA } & 2,05 \\
\hline
\end{tabular}
areia. Após peneirada, com o auxílio do agitador mecânico, foram pesadas todas as peneiras com areia retida, conforme apresentado na Tabela 9.

\section{Granulometria - Areia Média Lavada}

Tabela 9 - Ensaio de granulometria da areia média lavada

Fonte: Autores, 2020

Com a composição granulométrica, foi possível obter a porcentagem retida acumulada, com esse valor e utilizando da equação abaixo foi possível obter o valor do módulo de finura da areia média lavada.

$$
M F=\frac{\sum \% \text { retida acumulada }}{100}
$$




\subsubsection{Massa específica da areia}

Tendo sido realizado o ensaio de frasco de chapman, foi possível obter as leituras com relação a massa específica do material, obtendo-se os valores que apresentados abaixo.

$$
\begin{gathered}
m=\frac{500}{L-200} \\
m 1=\frac{500}{390-200} \\
m 1=2,631 \frac{g}{c m^{3}} \\
m 2=\frac{500}{391-200} \\
m 2=2,618
\end{gathered}
$$

\subsection{Rompimento dos corpos de prova cilíndricos a compressão axial}

Com os corpos de prova cilíndricos moldados e seguindo as recomendações da NBR 7215:2019, os corpos de prova foram rompidos com o auxílio de uma máquina que gradativamente aplica cargas de compressão, sobre o corpo de prova até o mesmo se romper (Figura 19).

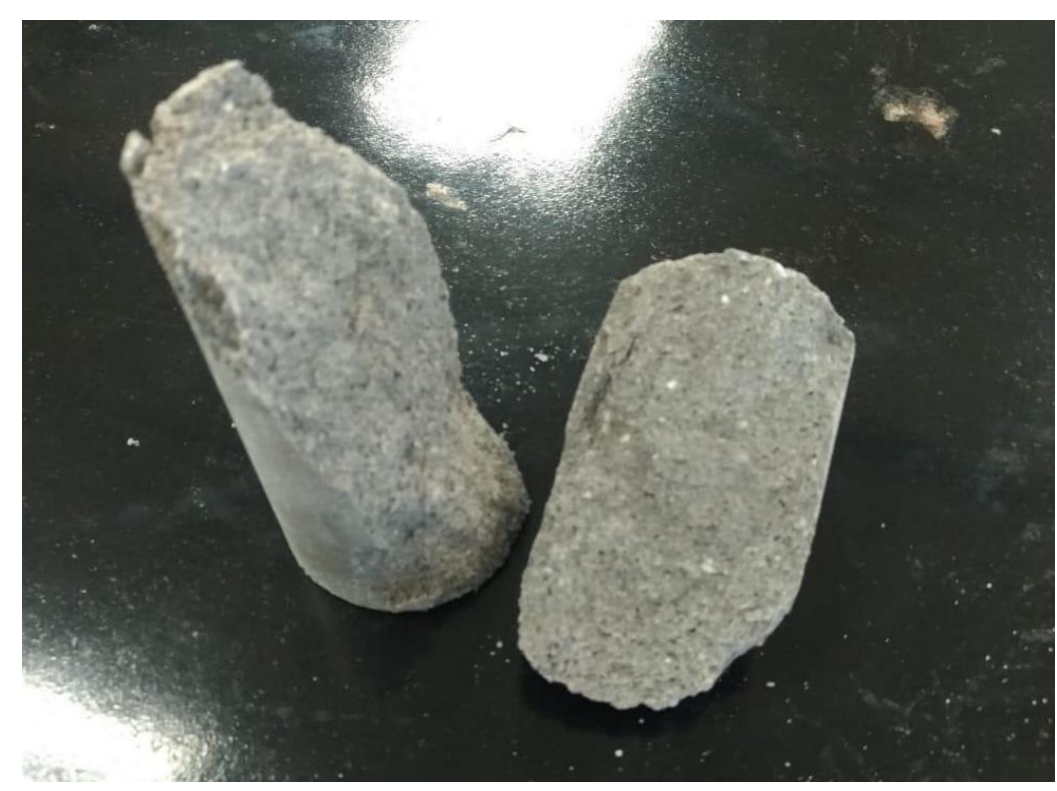

Figura 19 - Rompimento sob compressão axial

Fonte: Autores, 2020

\subsubsection{Compressão axial CPII-Z-32}

Utilizando a prensa hidráulica, equipamento responsável pela aplicação de cargas nos corpos de prova, foi possível obter os valores em que os corpos de prova de cada traço para o cimento CPII-Z-32 se rompiam, os valores foram coletados com 3, 7 e 28 dias de cura úmida e podem ser observados na Tabela 10. 


\begin{tabular}{c|c|c}
\hline \multicolumn{3}{|c}{ Compressão Axial (CPII-Z) } \\
\hline \multirow{4}{*}{3} & Referência & 12,73060916 \\
\cline { 2 - 3 } & $5 \%$ & 10,27752078 \\
\cline { 2 - 3 } & $10 \%$ & 10,54245325 \\
\hline \multirow{4}{*}{$\mathbf{7}$} & $15 \%$ & 10,33325249 \\
\cline { 2 - 3 } & Referência & 19,12785131 \\
\cline { 2 - 3 } & $5 \%$ & 13,56429749 \\
\hline \multirow{3}{*}{$\mathbf{n y y}$} & $10 \%$ & 15,47362899 \\
\cline { 2 - 3 } & $15 \%$ & 11,36959391 \\
\cline { 2 - 3 } & Referência & 22,07283293 \\
\hline
\end{tabular}

Tabela 10 - Resultados de Compressão Axial do CPII-Z

Fonte: Autores, 2020

Com base nos dados coletados, foi possível observar que os corpos de prova que foram submetidos a compressão axial obtiveram resultado abaixo do valor de referência, porém com 28 dias o valor de substituição de 15\% está bem próximo ao valor de referência (Gráfico 1).

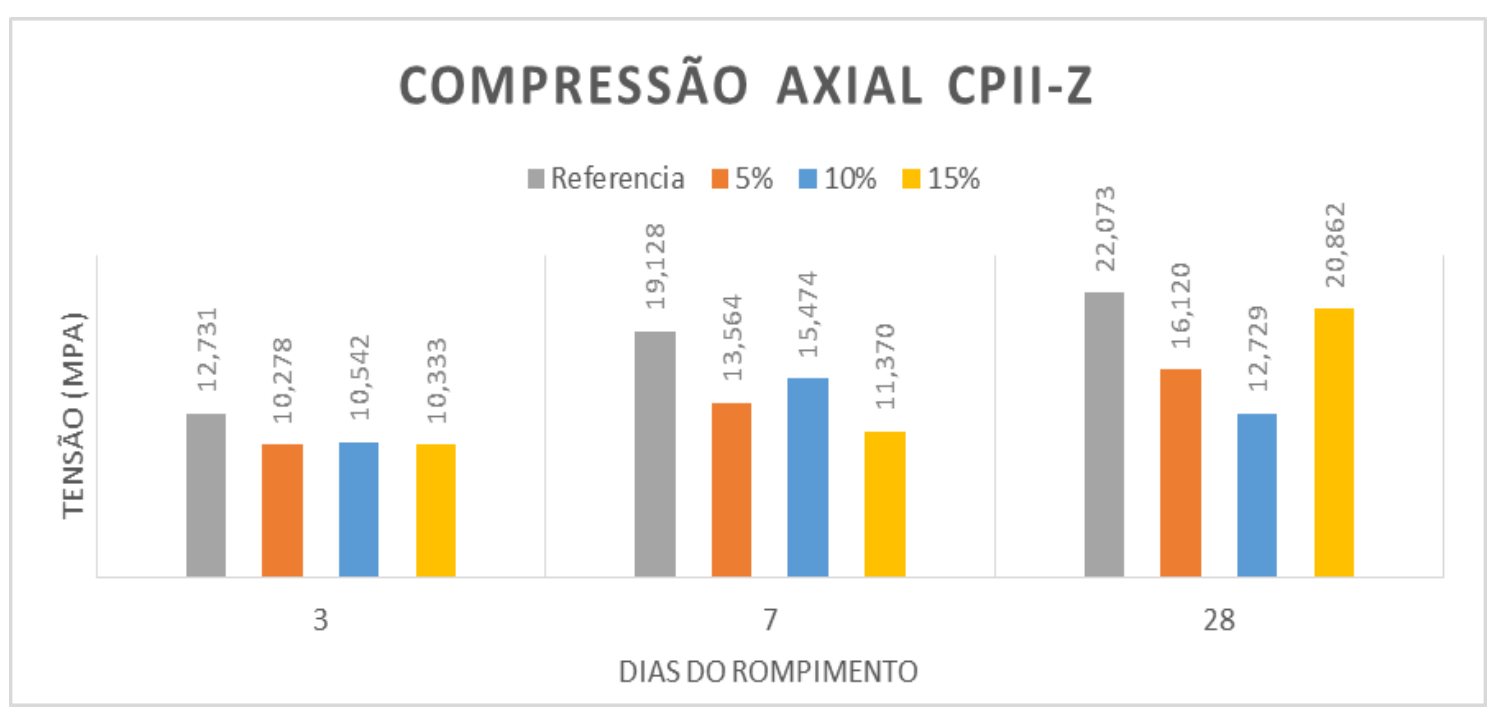

Gráfico 1 - Compressão Axial CPII-Z

Fonte: Autores, 2020

4.4.2. Compressão axial CPV-ARI

Utilizando a prensa hidráulica, equipamento responsável pela aplicação de cargas nos corpos de prova, foi possível obter os valores em que os corpos de prova de cada traço para 
o cimento CPV-ARI se rompiam, os valores foram coletados com 3, 7 e 28 dias de cura úmida e podem ser observados na Tabela 11.

\begin{tabular}{c|c|c}
\hline \multicolumn{2}{c}{ Compressão Axial (CPV-ARI) } \\
\hline \multirow{4}{*}{3} & Referência & 18,48306814 \\
\cline { 2 - 3 } & $5 \%$ & 12,3432332 \\
\cline { 2 - 3 } & $10 \%$ & 7,157773559 \\
\cline { 2 - 3 } & $15 \%$ & 7,768443446 \\
\cline { 2 - 3 } 7 & Referência & 10,27870847 \\
\cline { 2 - 3 } & $5 \%$ & 14,9453896 \\
\cline { 2 - 3 } & $10 \%$ & 13,87764832 \\
\hline \multirow{4}{*}{28} & $15 \%$ & 9,53735459 \\
\cline { 2 - 3 } & Referência & 19,42222479 \\
\cline { 2 - 3 } & $5 \%$ & 26,56841821 \\
\cline { 2 - 3 } & $10 \%$ & 12,67451844 \\
\cline { 2 - 3 } & $15 \%$ & 18,65703991 \\
\hline
\end{tabular}

Tabela 11 - Resultados de Compressão Axial do CPV-ARI

Fonte: Autores, 2020

Ao se tratar de compressão axial os resultados apresentados na Tabela 11, mostram que a porcentagem de substituição de $5 \%$ (célula verde), obteve valor relevante aos 28 dias com relação às demais porcentagens, principalmente levando-se em consideração o valor de referência (Gráfico 2).

\section{COMPRESSÃO AXIAL CPV-ARI}

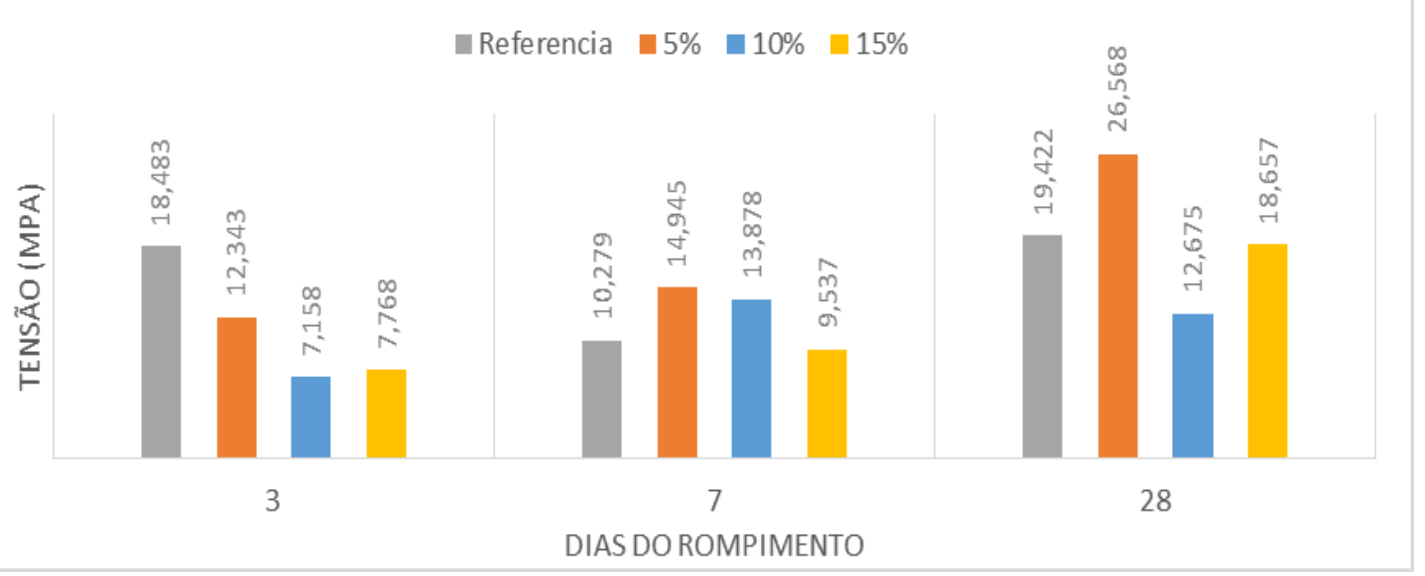

Gráfico 2 - Compressão Axial CPV-ARI

Fonte: Autores, 2020 
4.5. Rompimento dos corpos de prova cilíndricos a compressão diametral

De acordo com a NBR 7215:2019 e com o auxílio da máquina de compressão, foi possível coletar os dados de rompimento dos corpos de prova cilíndricos submetidos a compressão diametral (Figura 20).

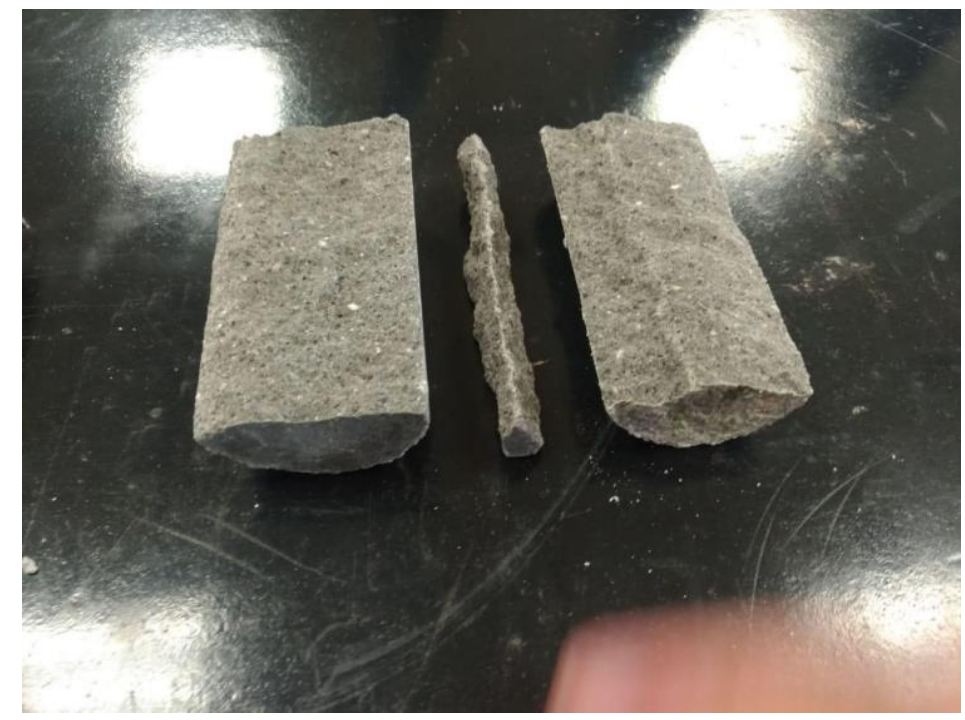

Figura 20 - Rompimento sob compressão diametral

Fonte: Autores, 2020

\subsubsection{Compressão diametral CPII-Z-32}

Os corpos de prova cilíndricos moldados com o cimento CPII-Z-32, foram submetidos a compressão diametral (Figura 21) na mesma máquina que realizou a compressão axial, nas idades de 3,7 e 28 dias. Para que fosse obtido o valor de compressão diametral, os corpos de prova foram colocados na máquina de compressão deitados, com o auxílio de um suporte para mantê-los firmes durante a compressão, os resultados podem ser observados na Tabela 12.

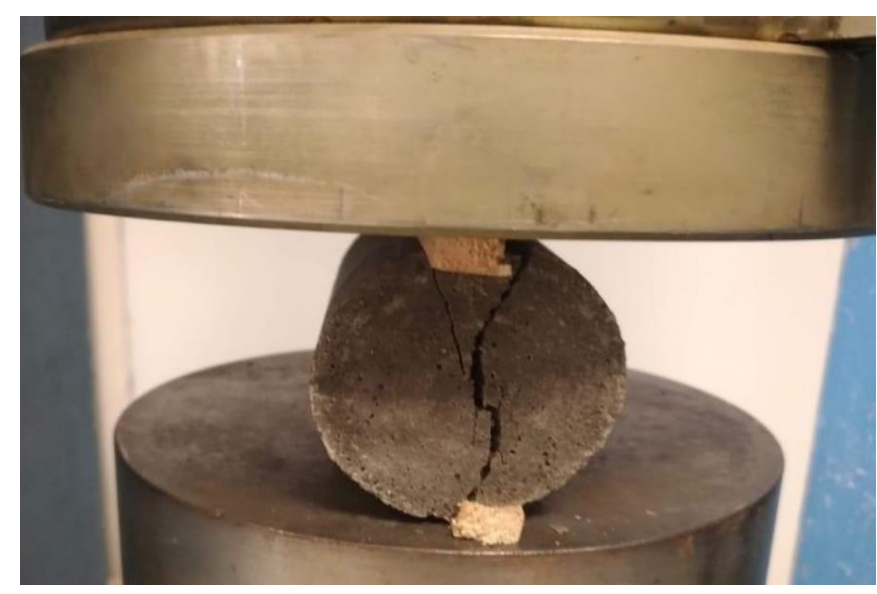

Figura 21 - Momento exato do rompimento sob compressão diametral Fonte: Autores, 2020 


\begin{tabular}{c|c|c}
\hline \multicolumn{2}{|c}{ Compressão Diametral (CPII-Z) } \\
\hline \multirow{4}{*}{3} & Referência & $\mathbf{1 , 9 2 2 6 8 5 9 1 5}$ \\
\cline { 2 - 3 } & $5 \%$ & 1,853961131 \\
\cline { 2 - 3 } & $10 \%$ & 1,705444173 \\
\hline \multirow{4}{*}{7} & $15 \%$ & 1,506675248 \\
\cline { 2 - 3 } & Referência & 2,24855168 \\
\cline { 2 - 3 } & $5 \%$ & $\mathbf{2 , 2 8 6 1 3 2 6 7 6}$ \\
\hline \multirow{4}{*}{$\mathbf{n y y}$} & $10 \%$ & 1,998379537 \\
\cline { 2 - 3 } & $15 \%$ & 1,623426396 \\
\cline { 2 - 3 } & Referência & 2,964706964 \\
\cline { 2 - 3 } & $5 \%$ & $\mathbf{3 , 1 3 8 8 0 8 7 9}$ \\
\hline
\end{tabular}

Tabela 12 - Resultados de Compressão Diametral do CPII-Z

Fonte: Autores, 2020

Nos resultados dos ensaios de compressão diametral é possível observar que nas idades de 3 e 7 dias, os corpos de prova possuem resistências similares, no entanto na idade de 28 dias o valor da substituição de $5 \%$ obteve um ganho significativo de resistência se comparado ao valor de referência (Gráfico 3).

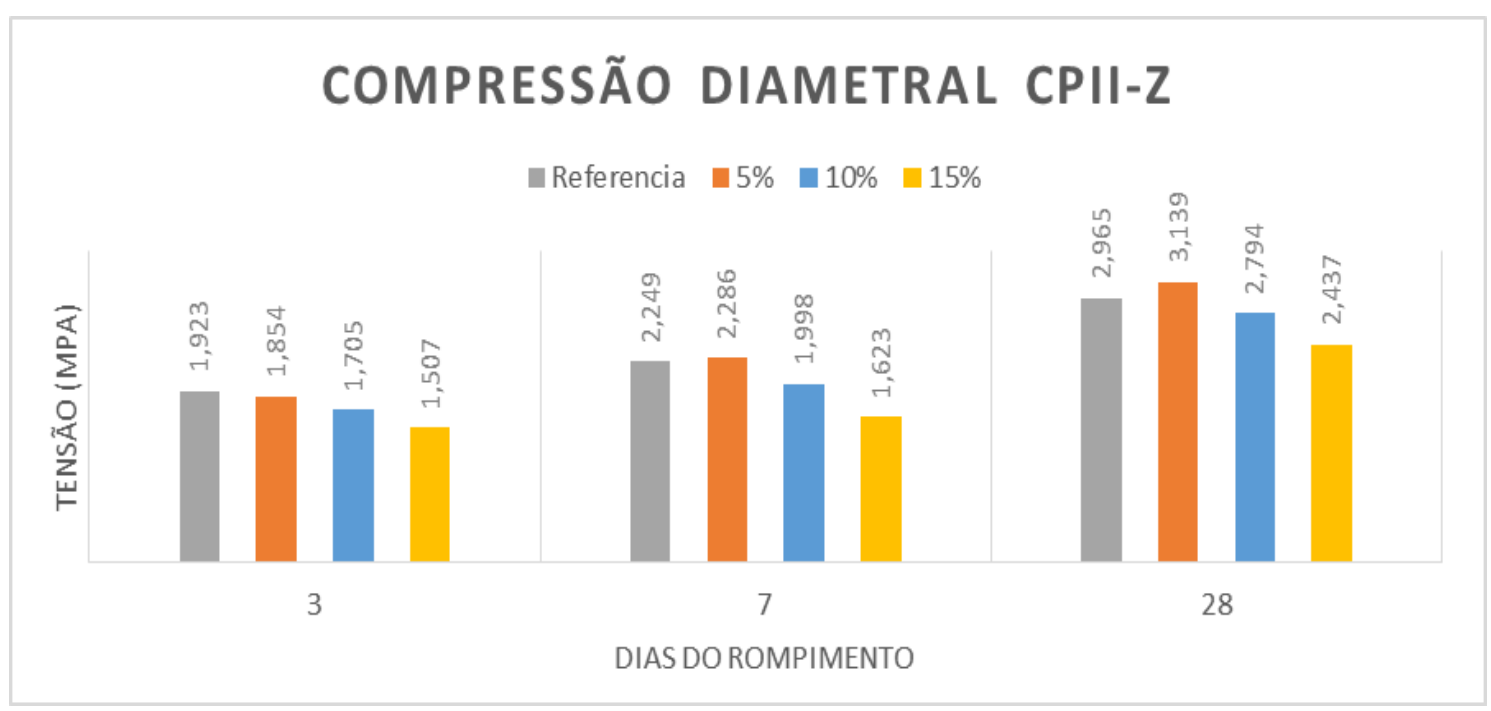

Gráfico 3 - Compressão diametral CPII-Z

Fonte: Autores, 2020

\subsubsection{Compressão diametral do CPV-ARI}

Os corpos de prova cilíndricos moldados com o cimento CPV-ARI, foram submetidos ao mesmo processo que os corpos moldados com CPII, nas idades de 3,7 e 28 dias. Para que fosse obtido o valor de compressão diametral, os corpos de prova foram colocados na 
máquina de compressão deitados, com o auxílio de um suporte para mantê-los firmes durante a compressão, os resultados podem ser observados na Tabela 13.

\begin{tabular}{c|c|c}
\hline \multicolumn{2}{|c}{ Compressão Diametral (CPV) } \\
\hline \multirow{4}{*}{3} & Referência & 2,021074466 \\
\cline { 2 - 3 } & $5 \%$ & 1,987045332 \\
\cline { 2 - 3 } & $10 \%$ & $\mathbf{2 , 0 3 4 9 8 6 6 0 9}$ \\
\hline \multirow{4}{*}{$\mathbf{7}$} & $15 \%$ & 1,607976977 \\
\cline { 2 - 3 } & Referência & $\mathbf{3 , 1 2 3 9 6 7 9 1 8}$ \\
\cline { 2 - 3 } & $5 \%$ & 2,341915494 \\
\hline \multirow{4}{*}{$\mathbf{2 8}$} & $10 \%$ & 2,164461829 \\
\cline { 2 - 3 } & $15 \%$ & 2,480020168 \\
\cline { 2 - 3 } & Referência & 3,9106815 \\
\cline { 2 - 3 } & $5 \%$ & 2,998645804 \\
\hline
\end{tabular}

Tabela 13 - Resultados de Compressão Diametral do CPV-ARI

Fonte: Autores, 2020

No que tange aos resultados de compressão diametral, somente o corpo de prova de 10\% de substituição apresenta valor maior que o de referência, na idade de 3 dias, porém seus valores ainda se mostraram positivos, já que não apresentam tanta discrepância com relação ao valor de referência (Gráfico 4).

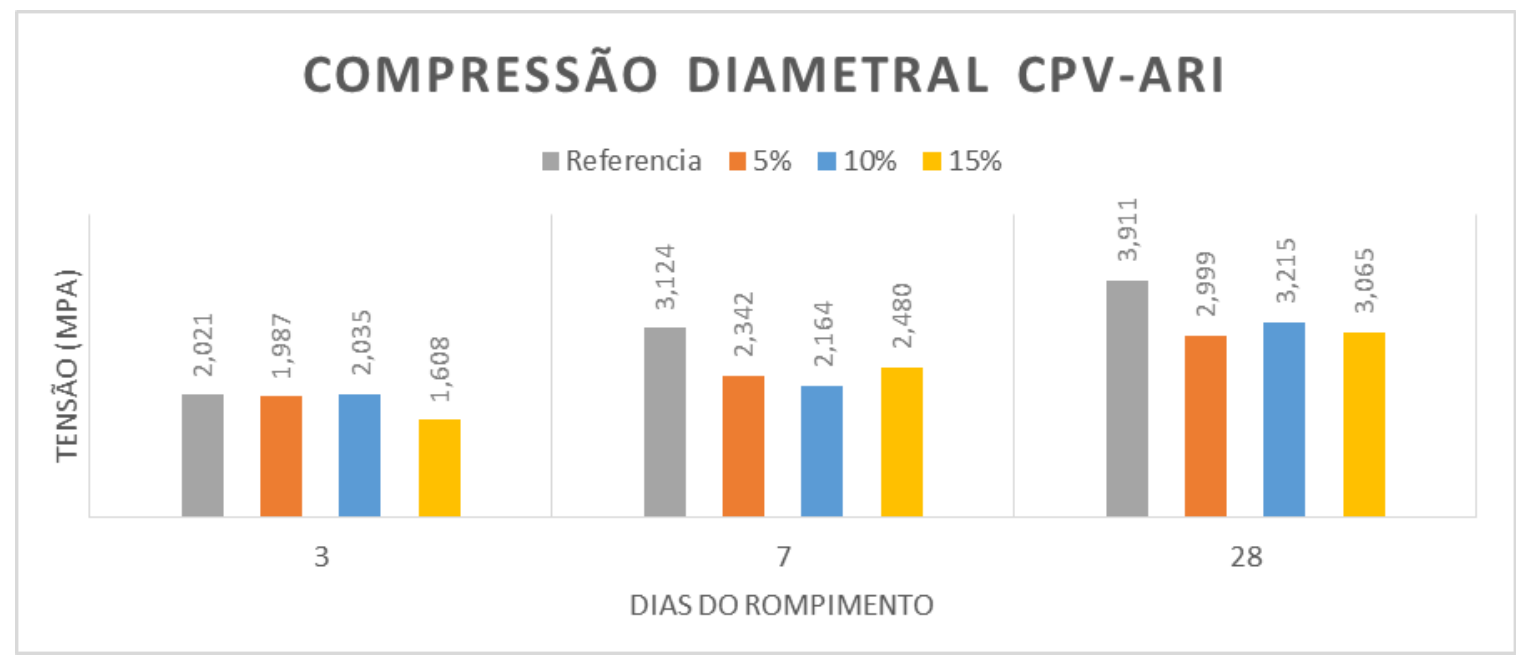

Gráfico 4 - Compressão diametral CPV-ARI

Fonte: Autores, 2020

4.6. Ensaio de flexão para corpos de provas prismáticos

Após desformados, os corpos de prova prismáticos moldados com CPII e com CPV, foram colocados em cura úmida, onde permaneceram até suas respectivas datas de rompimento. 
4.6.1. Ensaio de flexão para corpos de provas prismáticos moldados com CPII-Z-32

De acordo com a NBR 13279:2005 foram executados os ensaios de resistência à tração na flexão, nos corpos de prova prismáticos moldados com CPII-Z 32, para as idades de 3,7 e 28 dias. O rompimento se deu na mesma máquina em que foram realizados os rompimentos de compressão axial e diametral, porém utilizando um aparelho normatizado que transfere as forças do equipamento para a peça prismática flexionando-a. Os resultados podem ser observados na Tabela 14.

\begin{tabular}{l|c|c}
\hline \multicolumn{2}{c}{ CPII-Z } \\
\hline \multirow{4}{*}{3} & \multicolumn{2}{c}{ Tração na Flexão } \\
\cline { 2 - 3 } & Referência & $\mathbf{4 , 8 2 9 2 9 4 9 0 2}$ \\
\cline { 2 - 3 } & $5 \%$ & 4,593646056 \\
\cline { 2 - 3 } & $10 \%$ & 4,462250191 \\
\hline \multirow{4}{*}{7} & $15 \%$ & 3,909342036 \\
\cline { 2 - 3 } & Referência & $\mathbf{5 , 6 6 2 6 2 0 9 4 3}$ \\
\cline { 2 - 3 } & $5 \%$ & 5,39627158 \\
\hline \multirow{3}{*}{$\mathbf{2 8}$} & $10 \%$ & 5,041506908 \\
\cline { 2 - 3 } & $15 \%$ & 4,33524809 \\
\cline { 2 - 3 } & Referência & 5,463048814 \\
\cline { 2 - 3 } & $5 \%$ & $\mathbf{6 , 4 0 1 7 1 8 1 4 7}$ \\
\hline
\end{tabular}

Fonte: Autores, 2020

Nos corpos de prova prismáticos moldados com CPII-Z 32, para as idades de 3 e 7 dias, os corpos de prova obtiveram valores abaixo do de referência, porém aos 28 dias o resultado foi o oposto, ou seja, todas as porcentagens obtiveram valores acima do valor de referência, conforme pode ser observado no Gráfico 5. 


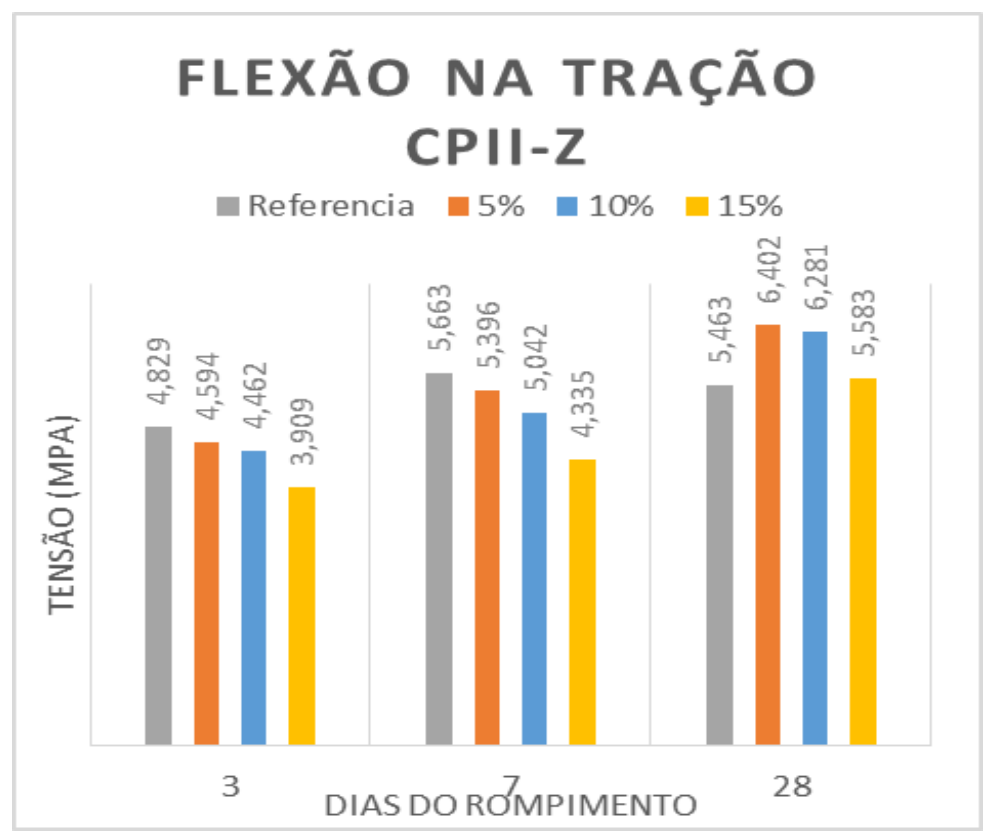

Gráfico 5 - Flexão na tração CPII-Z

Fonte: Autores, 2020

4.6.2. Ensaio de flexão para corpos de provas prismáticos moldados com CPV-ARI

De maneira similar os corpos de prova moldados com CPV-ARI foram submetidos ao ensaio de tração na flexão, nas idades de 37 e 28 dias. Os resultados podem ser observados Tabela 15 e Gráfico 6.

\begin{tabular}{l|c|c}
\hline \multicolumn{2}{c}{ CPV } \\
\hline \multirow{4}{*}{3} & Referência & Tração na Flexão \\
\cline { 2 - 3 } & $5 \%$ & $\mathbf{5 , 8 8 8 4 2 2 2 5 1}$ \\
\cline { 2 - 3 } & $10 \%$ & 5,880502692 \\
\cline { 2 - 3 } & $15 \%$ & 4,892635445 \\
\hline \multirow{4}{*}{$\mathbf{7}$} & Referência & 3,78685949 \\
\cline { 2 - 3 } & $5 \%$ & $\mathbf{7 , 7 9 9 7 8 5 2 2 5}$ \\
\cline { 2 - 3 } & $10 \%$ & 6,373966104 \\
\hline \multirow{3}{*}{$\mathbf{2 8}$} & $15 \%$ & 6,502408209 \\
\cline { 2 - 3 } & Referência & 4,127478774 \\
\cline { 2 - 3 } & $5 \%$ & 7,777162673 \\
\cline { 2 - 3 } & $10 \%$ & $\mathbf{7 , 8 5 4 7 8 0 9 7 3}$ \\
\hline
\end{tabular}

Tabela 15 - Resultados de Tração na Flexão do CPV-ARI

Fonte: Autores, 2020

De acordo com a ABNT NBR 13279:2005, obteve-se resultados satisfatórios com os corpos de prova prismáticos, principalmente para a porcentagem de substituição de $5 \%$, o 
qual nas idades de 3 e 7 dias apresentou resultados similares ao de referência, e aos 28 dias superou o valor de referência.

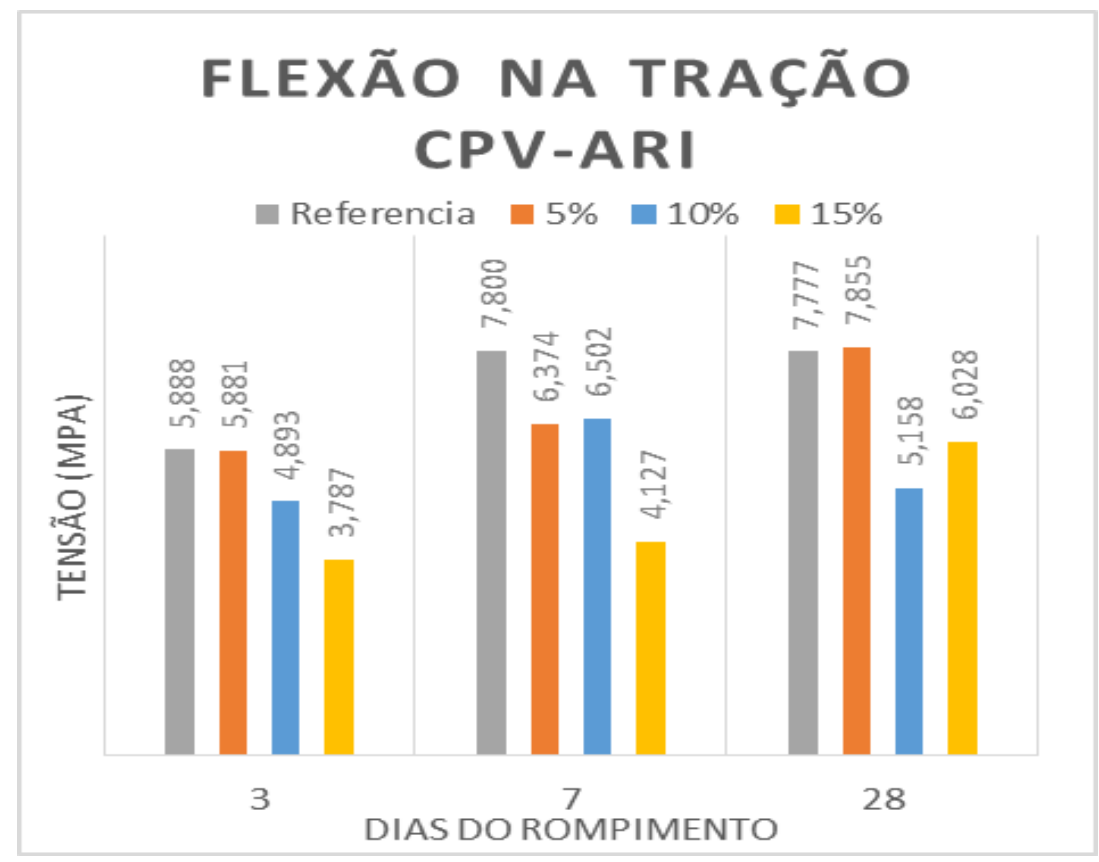

Gráfico 6 - Flexão na tração CPV-ARI

Fonte: Autores, 2020

4.7. Rompimento dos corpos de prova de concreto

Devido ao ótimo desempenho dos corpos de prova moldados com CPV-ARI foram moldados os corpos de prova de concreto, que foram confeccionados para serem rompidos nas idades de 1, 3, 7, 28 e 90 dias.

Infelizmente devido a pandemia da COVID-19, não foi possível obter os dados correspondentes aos rompimentos nas idades de 28 e 90 dias.

4.7.1. Compressão axial corpos de prova de concreto

Os corpos de prova de concreto, moldados com o cimento CPV-ARI, foram rompidos com 1, 3 e 7 dias, de acordo com a NBR 5739:2018 - Ensaio de compressão de corpos de prova cilíndricos. Foram rompidas 3 amostras em cada dia de cada proporção e feita uma média entre eles. Os resultados podem ser observados Tabela 16. 


\begin{tabular}{|c|c|}
\hline \multicolumn{2}{|c|}{ Compressão axial } \\
\hline \multicolumn{2}{|c|}{1 dia } \\
\hline Substituiçao & Tensão Máxima (Mpa) \\
\hline $0 \%$ & 11,600 \\
\hline $5 \%$ & 12,992 \\
\hline $15 \%$ & 8,262 \\
\hline $20 \%$ & 8,654 \\
\hline \multicolumn{2}{|c|}{3 dias } \\
\hline Substituiçao & Tensão Máxima (Mpa) \\
\hline $0 \%$ & 16,020 \\
\hline $5 \%$ & 17,090 \\
\hline $15 \%$ & 14,256 \\
\hline $20 \%$ & 15,144 \\
\hline \multicolumn{2}{|c|}{7 dias } \\
\hline Substituiçao & Tensão Máxima (Mpa) \\
\hline $0 \%$ & 21,070 \\
\hline $5 \%$ & 22,500 \\
\hline $15 \%$ & 17,627 \\
\hline $20 \%$ & 19,421 \\
\hline
\end{tabular}

Fonte: Autores, 2020

Como pode ser verificado, em todas as idades os valores observados foram muito semelhantes em cada um dos traços, porém todos os dados ficaram acima do valor de referência nas idades de 1 e 3 dias. Com relação à idade de 7 dias, os valores obtidos com os concretos com uso de granalha de aço, mesmo abaixo do valor de referência, não foram muito destoantes o que não inviabiliza a sua utilização na mistura do concreto.

4.7.2. Compressão diametral dos corpos de prova de concreto

Para este ensaio foram utilizados 3 corpos de prova para cada traço, o qual seguiu as prerrogativas da NBR 5739:2018 - Ensaio de compressão de corpos de prova cilíndricos. Os resultados podem ser observados na Tabela 17. 
Compressão diametral

\begin{tabular}{|c|c|}
\hline \multicolumn{2}{|c|}{1 dia } \\
\hline Substituição & Tensão Máxima (Mpa) \\
\hline $0 \%$ & 1,71 \\
\hline $5 \%$ & 2,25 \\
\hline $15 \%$ & 1,41 \\
\hline $20 \%$ & 1,53 \\
\hline \multicolumn{2}{|c|}{3 dias } \\
\hline Substituição & Tensão Máxima (Mpa) \\
\hline $0 \%$ & 1,89 \\
\hline $5 \%$ & 2,75 \\
\hline $15 \%$ & 1,82 \\
\hline $20 \%$ & 1,96 \\
\hline \multicolumn{2}{|c|}{7 dias } \\
\hline Substituição & Tensão Máxima (Mpa) \\
\hline $0 \%$ & 2,46 \\
\hline $5 \%$ & 3,04 \\
\hline $15 \%$ & 2,18 \\
\hline $20 \%$ & 2,25 \\
\hline
\end{tabular}

Fonte: Autores, 2020

De acordo com a análise realizada, os valores de $5 \%$ obtiveram valores maiores em todas as idades, porém os demais valores não se apresentam tão destoantes. Vale destacar que na idade de 3 dias, dentre todas as substituições o valor de referência foi o menor, o que mostra a eficácia da substituição na mistura.

\section{CONSIDERAÇÕES FINAIS}

Dessa forma é possível observar que em se tratando dos corpos de prova moldados com cimento CPII-Z 32, os traços com substituição obtiveram valores relativamente menores em comparação ao de referência no ensaio de compressão axial, sendo que o traço com 15\% de substituição obteve o melhor resultado

Com relação ao ensaio de flexão, todos os resultados referentes aos traços com substituição obtiveram valores superiores ao traço de referência para a idade de 28 dias, e em se tratando do ensaio de resistência a tração a porcentagem de $5 \%$ obteve o melhor resultado, com relação ao traço de referência e também aos 28 dias.

Nas misturas realizadas com o cimento CPV-ARI, de alta resistência inicial, foi possível observar resultados positivos, onde observou-se que com a porcentagem de substituição de $5 \%$ é possível obter resultados ainda melhores que os valores padrões de referência. 
Quando falamos das propriedades do concreto propriamente dito, que foi moldado utilizando o cimento CPV-ARI, é importante ressaltar que o melhor valor foi o de $5 \%$, apresentando a maior resistência dentre todas as amostras em todas as idades quando falamos de compressão diametral, já na compressão axial o único valor superior foi o de referência que supera o valor em questão por apenas uma casa decimal, valor esse que pode ser considerado insignificante.

É relevante destacar que durante à pesquisa, foram utilizadas várias porcentagens de substituição de resíduo de granalha por cimento, a fim de verificar qual dessas apresentaria melhor desempenho, é fato que se observou perdas de resistência mecânica em porcentagens distintas. Apesar disso, os valores resultantes das análises não desqualificam o uso da mistura, isto é, a mesma pode vir a ter bom desempenho dependendo do uso que for dado à mesma, tendo em vista que as perdas analisadas não foram muito significativas, estando muito próximo ao valor de referência. É claro, que para melhor avaliação do desempenho do uso de resíduo de granalha de aço em concreto está condicionada a outros ensaios físicos e químicos, dando assim continuidade à pesquisa em questão.

Quanto a corrosão e durabilidade das misturas, seria necessário que fossem realizados experimentos específicos para determinar se há ou não uma mudança significativa nesses aspectos, sendo um bom ponto de partida para pesquisas futuras que se proponham a dar continuidade ao estudo em tela com relação.

Sendo assim, é possível observar que a substituição parcial de cimento por resíduo de granalha de aço é promissora, tendo em vista que é possível obter resultados satisfatórios ou até melhor do que o esperado em se tratando de resistência a tração e flexão, e tendo uma redução significativa de cimento na mistura, material esse que como exposto traz consigo durante sua produção uma carga poluidora que impactam o meio ambiente.

Em pesquisas futuras é possível estudar diferentes porcentagens e materiais alternativos para a mistura, como cimentos de marcas e propriedades diferentes, que podem ser utilizados para se aprimorar os resultados que nesse primeiro estudo se mostraram promissores. 


\section{REFERÊNCIAS}

CALLISTER Jr., William D.; RETHWISCH,David G. Fundamentos da Ciência e Engenharia de Materiai: Uma Abordagem Integrada. 4. ed. LTC, 2014

METHA, P.K., MONTEIRO, P.J.M. Concreto - Estrutura, Propriedades e Materiais. São Paulo SP, Editora PINI, 1994.

R.C, Hibbler. Resistência dos materiais. 7. ed. São Paulo: AFILIADA, 2010

ARISTIMUNHO, Péterson B.; BERTOCINI, Sandra R. Aplicação de lama de minério de ferro em forma de pó na presença de cimento portland. Revista IBRACOM de Estruturas e Materiais, Volume 5, Número 2, Abril, 2012

AGUIAR, M.A.M.; FERREIRA, K.C.; OLIVEIRA, M.F.M; SILVA, A.Q.N; PERES, A.E.C. Utilização de Resíduos de Minério de Ferro como Matéria-Prima para Fabricação de Argamassa; XXVI Encontro Nacional de Tratamento de Minérios e Metalurgia Extrativa Poços de Caldas-MG, 18 a 22 de Outubro 2015

PINHEIRO, Libânio M; MUZARDO, Cassiane D; SANTOS, Sandro P. ESTRUTURAS DE CONCRETO - CAPÍTULO 2. USP- Departamento de Engenharia de Estrutura.Março, 2014

ALMEIDA, Luiz C. AU414 - Estruturas IV - Concreto armado. FEC . Agosto, 2012

MAURY, Maria B; BLUMENSCHEIN, Raquel N. Produção de cimento: Impactos à saúde e ao meio ambiente. . Sustentabilidade em Debate - Brasília, 201

MAGALHÃES, Luciano F. Avaliação do Rejeito de minério de ferro como material cimentício suplementar. CEFET-MG. Belo Horizonte, 2018

NARCISO, Carolina R. Influência do Resíduo de Minério de na Produção de Painéis Cimento Madeira. UFLA. Lavras - MG, 2018

PEREIRA, Schubert Jr. Desenvolvimento de Argamassas Contendo Resíduos Arenosos de Mineração e Estudos de suas Propriedades Visando sua Utilização. CDTN. Belo Horizonte, Março,2011

ASSOCIAÇÃO BRASILEIRA DE NORMAS TÉCNICAS. NBR 5739: Concreto - Ensaio de compressão de corpos de prova cilíndricos. Rio de Janeiro, 2018.

ASSOCIAÇÃO BRASILEIRA DE NORMAS TÉCNICAS. NBR 7215: Cimento Portland Determinação da resistência á compressão de corpos de prova cilíndricos, Rio de Janeiro, 2019.

ASSOCIAÇÃO BRASILEIRA DE NORMAS TÉCNICAS. NBR 11579: Cimento Portland Determinação do índice de finura por meio da peneira 75 m (no 200), Rio de Janeiro, 2012. 
ASSOCIAÇÃO BRASILEIRA DE NORMAS TÉCNICAS. NBR 7211: Agregado para concretos Especificação. Rio de Janeiro: ABNT, 2009

ASSOCIAÇÃO BRASILEIRA DE NORMAS TÉCNICAS. NBR 16606: Cimento Portland Determinação dos tempos de pega, Rio de Janeiro, 2018.

ASSOCIAÇÃO BRASILEIRA DE NORMAS TÉCNICAS. NBR 16607: Cimento Portland Determinação da pasta de consistência normal, Rio de Fonte: autora, 2020.

Janeiro, 2018.

ASSOCIAÇÃO BRASILEIRA DE NORMAS TÉCNICAS. NBR 9776: Agregados -Determinação da massa específica de agregados miúdos por meio do frasco chapman - Método de ensaio), Rio de Janeiro, 1987.

ASSOCIAÇÃO BRASILEIRA DE NORMAS TÉCNICAS. NBR 7214: Areia normal para ensaio de cimento - Especificação, Rio de Janeiro, 2015.

JOHN, V., AGOPYAN, V. Reciclagem de resíduos da construção. Disponível em: https://www.researchgate.net/publication/228600228_Reciclagem_de_residuos_da_constr ucao, acessado em 30/01/19.

EARTH INSTITUTE/ COLUMBIA UNIVERSITY. Disponível em: https://blogs.ei.columbia.edu/2012/05/09/emissions-from-the-cement-industry/ SINTO BRASIL PRODUTOS LIMITADA. Disponível www.sinto.com.br

FERREIRA, Ricardo. Traço de Concreto. Disponível em: http://professor.pucgoias.edu.br/SiteDocente/admin/arquivosUpload/15030/material/puc_ maco2_07_traco.pdf 